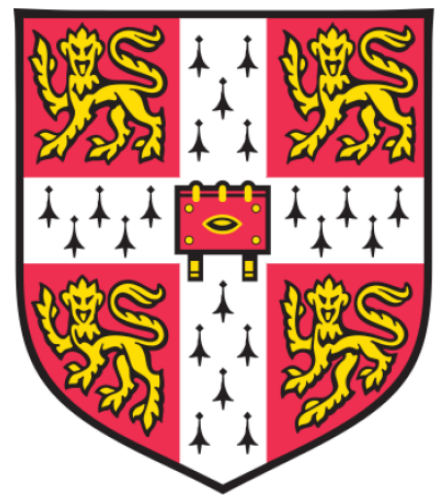

University of Cambridge

Institute of Criminology

MPhil in Criminological Research

Supervised by Dr Ben Crewe

\title{
Turning points or dead ends? Identity, desistance and the experience of imprisonment
}

\author{
Ben Jarman \\ Robinson College
}

10th August 2017 


\section{Declaration}

This dissertation is the result of my own work and includes nothing which is the outcome of work done in collaboration, except where specifically indicated in the text. This dissertation does not exceed the word limit as set out by the Degree Committee of the Faculty of Law. The total word count is 17,963 words.

Signed:

(Ben Jarman)

Submitted: 


\section{Acknowledgements}

My first thanks are to the prisoners I interviewed, for being as open and generous with their stories as they felt able. I hope the interpretation presented here does justice to what they said. Staff at Gartree helped with sampling, access, and practicalities such as room bookings. I received ad hoc assistance from too many people to name, but must specifically acknowledge Jon Auty, Katie Homer and Emma Allcock, whose contributions were indispensable. Thanks are also due to Gartree's governors, Michael Wood and Ali Barker, for permitting the study to take place and allowing me to draw keys. Peter and Judith Devine let me stay with them near the prison, and Caroline and Mark Tapp lent me their car; all of this practical help made fieldwork run smoothly.

My supervisor Dr Ben Crewe commented on an early draft of the interview schedules presented in this dissertation, as did Dr Caroline Lanskey. The Institute of Criminology in general has been a stimulating environment and I thank all the staff there for making it so, but I owe particular thanks to Ben, who has made himself available throughout the year with intellectual guidance, practical advice, and reassurance where needed, but has also encouraged me to have confidence in my own judgment. It has been a productive and an enjoyable relationship, and I hope it will resume in the future. I should also thank Professor Sir Anthony Bottoms for sparing time to talk to me about his past research on desistance. This conversation set me thinking more broadly than before, and it later helped me think about how to deal with a more varied sample than I had envisaged. While writing this, I met weekly with a small group of friends from the course. We shared humour, support, advice, and gossip, and also talked about our research from time to time. Thanks to Jenae, Patrick, Elinor and Claudia, who tolerated my puns and made the whole process of writing up much less painful.

I could not have started this degree, still less finished it, without the support of my parents and my partner Jo. I dedicate this work to them, and to my late grandfather Geoff Skinner: his own account of imprisonment in 1940s Austria would be that he 'made the best of a bad lot', but I learned about agency and structure from him long before I learned to use those terms to describe them. I wish he were still around to read this: in a way, it is a tribute to his influence, which runs deep in me. 


\section{Abstract}

Desistance research has pushed criminologists to develop a nuanced conceptual account of criminal identity and human agency. However, these tools have mostly not been used to consider identity changes among long-sentenced prisoners, despite the growing preponderance of long-term imprisonment in England and Wales. As a result of this, desistance theory has not been used to evaluate the administration of indeterminate sentences, meaning that practitioners may be missing out on some of the insights that it can generate. This qualitative study begins to fill that gap, using a phenomenological analysis of eighteen in-depth semi-structured interviews with lifesentenced prisoners at a single prison in England, all of whom had been convicted of murder. It argues that most eventually attempt conscious projects of personal change during imprisonment; second, that many frame change in terms which are not consistent with the official discourses of risk reduction (which govern their progression through the sentence); and third, that how they themselves conceive and pursue personal change is affected by their position in the sentence and the life course, and also by the specific nature and circumstances of their index offences. The analysis classifies four different styles of agency found in the sample: 'defensive' and 'fractured' agents were unwilling or unable to accept responsibility for the offence, and were consequently in penal 'dead ends'; while 'corrective' and 'redemptive' agents had encountered 'turning points', in that they accepted responsibility, albeit in different ways. The analysis describes each group's characteristic ways of describing the offence and their part in it. It also describes their attitudes to prison social life in general, and to rehabilitative intervention in particular. The study as a whole suggests that much of the personal change which lifers themselves frame as significant happens outside rehabilitative interventions, and may be invisible to key prison staff. This raises important questions about whether prisons and prisoners think about rehabilitation in the same way, with consequences for the legitimacy of penal power. 


\section{Contents}

Declaration

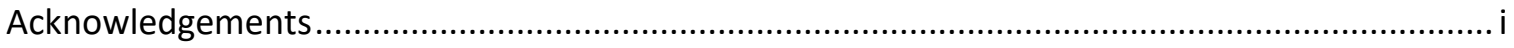

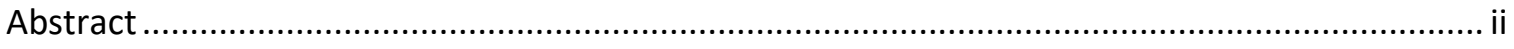

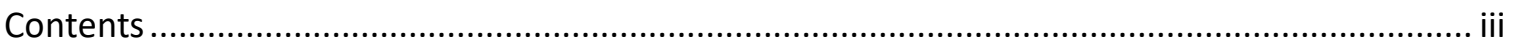

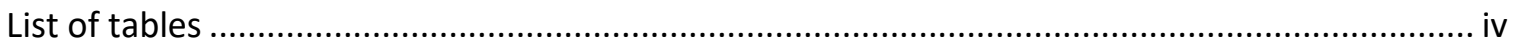

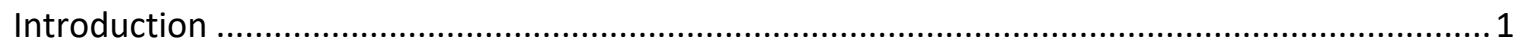

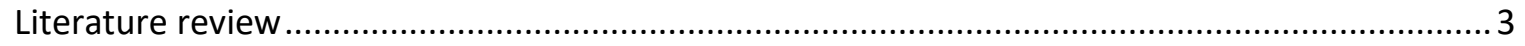

Risk vs. character: two conceptions of personhood ................................................................ 3

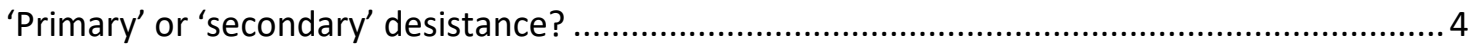

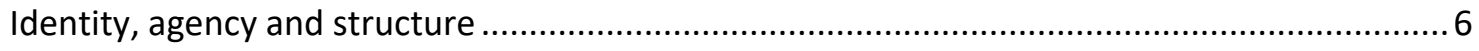

The effects of long-term imprisonment upon identity ......................................................... 9

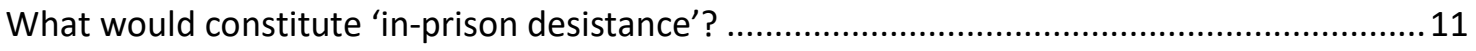

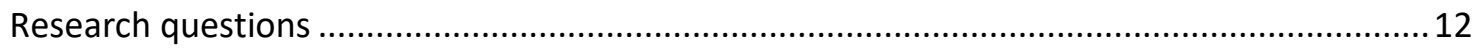

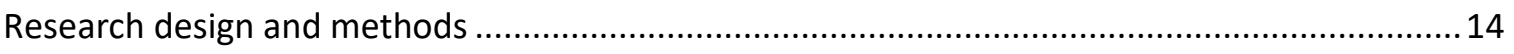

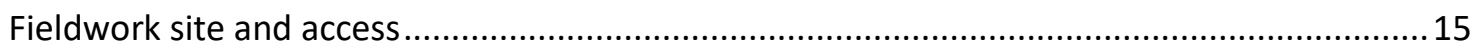

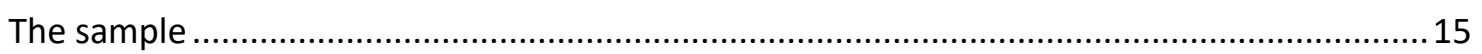

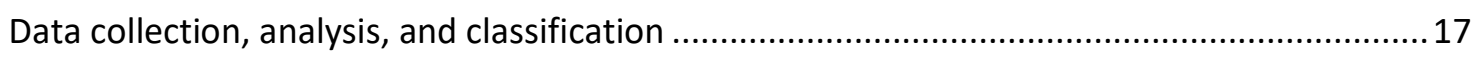

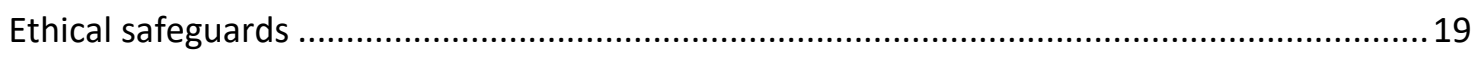

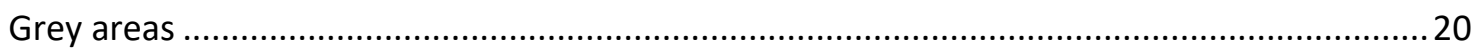

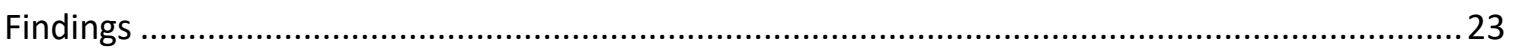

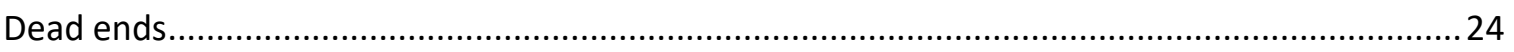

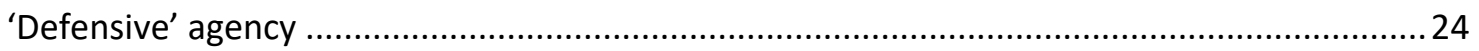

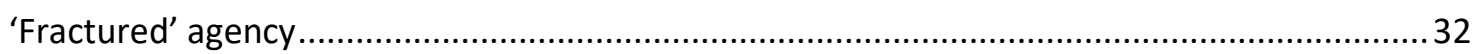

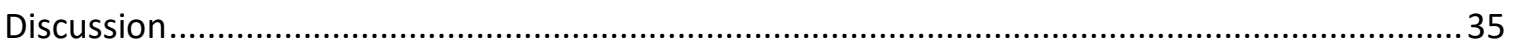

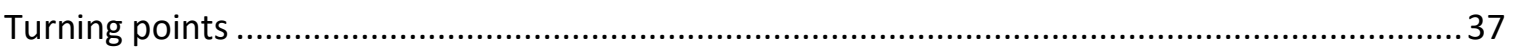

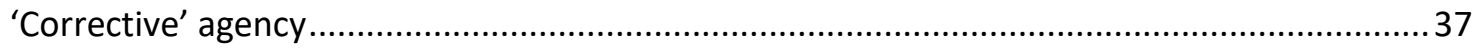

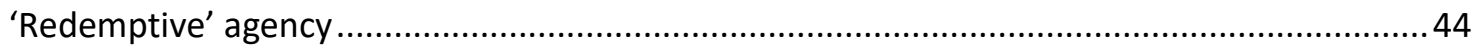

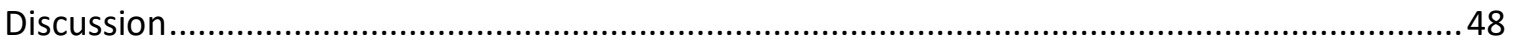

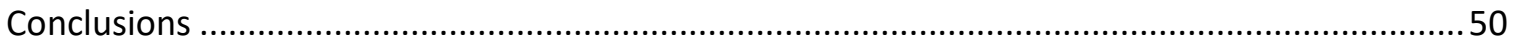

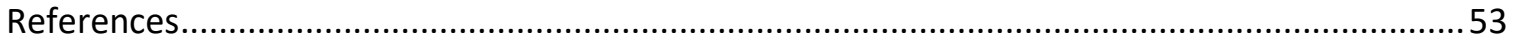

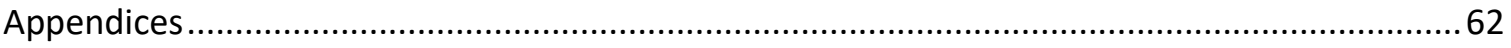

Appendix 1: Sentence and demographic information about prisoners in the sample ...............62

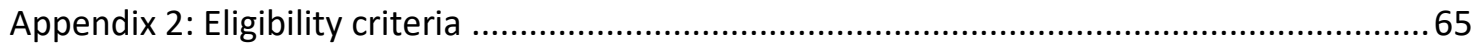

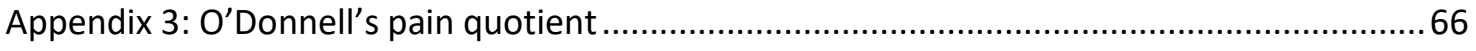


Appendix 4: Interview schedules

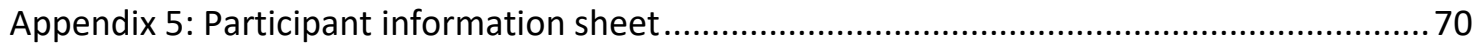

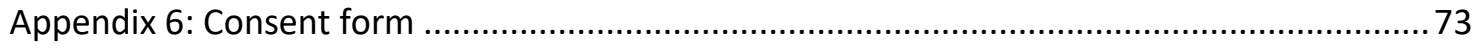

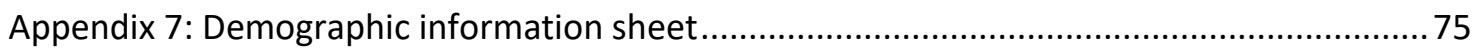

\section{List of tables}

Table 1: Frequency distribution of the sample $(n=18)$ by PQ rank and age when sentenced ....... 16

Table 2: Descriptive statistics for the sample $(n=18)$ and the eligible population $(n=489) \ldots \ldots \ldots . . .16$

Table 3: Summary information about the sample $(n=18)$, sorted in descending PQ order............62

Table 4: Mean demographic data for the analytical groups, sorted in descending PQ order .......64

Table 5: Original eligibility criteria, and whether they were applied............................................65 


\section{Chapter 1}

'Often, we presume that lives are halted when individuals enter prison, but this may be a flawed assumption; life-course transitions may occur, psychological well-being may fluctuate, criminal careers may persist, and the desistance process may unfold during periods of confinement.' (Kazemian and Travis 2015:361)

I have to thank Gartree, in a way [...] This place has changed a lot since I came here seven years ago, not all for the best, mostly it's just down, but... [long pause] This place changed me, you know? I have emotional ties here. I will always be thankful. It is like a dysfunctional home to me.' (Davidas)

\section{Introduction}

The average life-sentence tariff for murder grew from 12.5 to 21 years between 2003 and 2013. Lifers often remain in prison after the end of their tariffs, and some can struggle to access rehabilitative interventions. Yet only 3.5\% reoffend after release, compared to $46 \%$ of the overall prison population (PRT 2016:25). It is 'imperative' that desistance scholarship and life-course criminology pay greater attention to changes which might be taking place during long-term imprisonment (Kazemian and Travis 2015:376). This, they argue, would correct an excessive focus on the single outcome measure of reoffending, which in any case is generally low among long-sentenced prisoners (Ministry of Justice 2017:6).

Insights from desistance research have been used to challenge aspects of penal practice in areas such as offender supervision (e.g. Burnett and McNeill 2005; Fox 2014; McNeill 2006, 2012; Weaver 2014). If desistance scholarship has overlooked in-prison change, it is possible that further challenges should be mounted. Yet adapting desistance theory for this purpose requires care: prisons are a special kind of social environment, featuring 'an inherent legitimacy deficit [and] an unusually great disparity of power' (Sparks and Bottoms 1995:60), and exerting pronounced, though not always intended, influence over human agency (Crewe 2006, 2009).

This dissertation therefore borrows judiciously from research literatures on desistance and prison sociology, to consider identity change among life-sentenced prisoners. It assumes that most lifers understand that punishment demands change. But it asks how they themselves interpret this demand, and what kinds of desistance - that is to say, 'cognitive, social and behavioural changes' (Kazemian and Travis 2015:376) - 
they pursue. The central arguments developed are these: first, that most lifers convicted of murder eventually attempt conscious projects of personal change during imprisonment; second, that many frame change in terms consistent with the (re)building of 'character' (Sennett 1998), rather than penal discourses of risk reduction; and third, that their pursuit of change is affected by their positioning in the sentence and the life course, and also by the specific nature and circumstances of their index offences.

Chapter 2 selects key concepts from the two bodies of literature described above, using them to develop a working definition of what 'in-prison desistance' might entail. Two theoretical paradigms for rehabilitation are also compared: desistance and 'risk-needs-responsivity'. Chapter 3 describes the study's research design, methods, and sample, and explores ethical and methodological issues. In chapter 4 the findings are described and interpreted, starting with discussion of how the analysis has been organised and presented, and how the classification of styles of agency that follows has been generated and organised. Two groups of men are then described who were in 'dead ends'. Some used 'defensive' agency to resist the threat their convictions posed to their identity, denying or minimising the extent of their culpability. The agency of others was 'fractured': they considered themselves guilty but disowned the possibility of true responsibility, by suggesting they could not have acted differently.

Next, two further groups are described who embraced the idea that they should change, charting differences in how they thought about this process and pursued their goals. First, the agency of a younger group of prisoners who explicitly linked change to maturation and the hope of a better future is described as 'corrective'; then the 'redemptive' agency of a smaller, older group of prisoners more focused on atoning for a shameful past is discussed. The study's conclusions and limitations, along with what its findings might mean for future research, are outlined in chapter 5. 


\section{Chapter 2}

\section{Literature review}

In recent decades, desistance from crime has been 'perhaps the single most prominent topic of [criminological] research' (Warr 2016:234). Yet concepts from this literature have not been used to study how long-sentenced prisoners change during imprisonment (Kazemian and Travis 2015:377), despite the obvious potential of a separate sociological literature on the effects of imprisonment to cross-fertilise its conceptualisation. This chapter therefore considers how contemporary prisons think about rehabilitation, and then selects from research literatures on desistance and on adaptations to imprisonment to sketch out the conceptual basis for an exploratory study aiming to integrate the two.

\section{Risk vs. character: two conceptions of personhood}

Contemporary Anglo-Welsh prisons target rehabilitative resources using the 'risk-need-responsivity' model (Andrews and Bonta 2015, henceforth RNR). This classifies individuals as members of actuarially-defined risk-bearing groups, and 'treats' those held to pose the greatest risk of future harm, whose 'need' is thus defined, 'neopaternally', to be greatest (Crewe 2011b; Robinson 2008). This renders people as human packages of risk, or 'transformative risk subjects'(Feeley and Simon 1992; HannahMoffat 2005).

Critiques of RNR tend to highlight how this conception of personhood diverges from legal doctrines (and lay understanding) of responsibility for action (Hannah-Moffat 2013). Its 'pragmatic rather than theoretically deep or epistemically satisfactory' model of change (Polaschek 2016:172) facilitates the validation of specific interventions which 'treat' criminality, but potentially misses the influence of wider social environments surrounding those interventions. Desistance, by contrast, offers a subtler theory, in which individual change is the result of situated agency: it follows from individuals' reflexive evaluation of social roles and relationships, and specifically how they establish identities inconsistent with further offending by long-term participation in particular social settings (cf. Sennett 1998 on "character"). However, the impact of specific interventions is forbiddingly difficult to evaluate within this paradigm, because change is 
individual, zig-zagging, and lengthy. RNR therefore retains strong managerial appeal as a basis for targeting resources, but also errs fundamentally in placing the intervention, not the changing individual, at the heart of the process (McNeill 2012, 2016; though see Polaschek 2016 for a partial counter-argument).

Excessive focus on risk management can harm prisoners' interests and rights, even when the intention is to protect them (Genders and Player 2014; Hannah-Moffat 2014). The consequences for lifers are real: RNR contributes to sentence inflation via the 'back door' (Padfield 2005, 2016), partly because the 'complex requirements' (Liebling 2011:7) of risk reduction are so difficult to meet. Progression is mystified, depending on the creation and performance of a 'penal avatar' (Crewe 2011a:516; see also Cunha 2014:219-22) which may parallel the development of desisting 'character', but also be irreconcilable with it.

This study does not set out to evaluate the theoretical compatibility of these two paradigms. However, RNR (like all penal expertise) will generate illegitimacy if it cannot be politically and morally defended in terms intelligible to lay opinion (Sparks 1994; Sparks and Bottoms 1995, 2008). It matters how lifers themselves understand change, and whether they do so within risk-reducing discourse, because this affects the degree to which the demand to change can be said to be legitimate. It also matters if a focus on risk reduction crowds out principles identified by desistance research as important to penal practice, such as:

'being realistic about the complexity and difficulty of change; individualising support; building and sustaining hope; recognising and developing people's strengths; respecting and fostering agency (or self-determination); working with and through relationships (both personal and professional); developing social as well as human capital; and recognising and celebrating progress.' (McNeill et al. 2012:2)

\section{'Primary' or 'secondary' desistance?}

A significant theoretical divide in desistance literature is on whether research should explain the cessation of offending or changes in identity. Defining when offending has stopped is a methodological conundrum (Farrington 1986; Laub, Nagin, and Sampson 1998). Even the most prolific offenders are not committing crimes all (or even most) of the time (Wikström et al. 2012): in strict terms, they 'desist' during any gap between offences, and not all offending is detected. Demonstrating complete cessation is therefore hard, with two consequences: first, desistance is typically 
conceptualised as a process not an event (e.g. Paternoster and Bushway 2009:1110); and second, researchers must decide how far gaps and lulls in offending can be seen as 'desistance'. Some remain convinced that gaps and lulls should be what research aims to explain (e.g. Bottoms et al. 2004:371). Maruna and Farrall (2004), however, draw on labelling theory (Lemert 1951) to bracket gaps and lulls as 'primary' desistance, which they see as contingent, unpredictable and theoretically barren. They propose that research should investigate 'secondary' desistance: a 'reflective and more self-conscious break with previous [behaviour] patterns' (2004:174-75, emphasis in original), by which gaps coalesce into a 'non-criminal' identity. This definition of desistance is particularly appropriate if the population of interest is penologically, not criminologically, defined that is, if what its members have in common is punishment, not patterns of offending. This is the case for lifers and long-termers: considered as a group, they are criminologically quite dissimilar, unless efforts are made to subdivide them:

'[S]ome people who commit very serious offences [of the sort attracting long sentences] may not evidence any kind of 'criminal identity'. [Such an] identity is much more likely to be present for persistent, and not necessarily serious, offenders. The means of supporting desistance for the two groups are likely to be quite different.' (McNeill and Weaver 2010:5)

Research (like this study) which examines desistance among long-sentenced prisoners faces a conceptual dilemma, because there is no consistent pattern of behaviour they desist from. On the one hand, researchers can define subgroups whose patterns of behaviour are similar, and then investigate change in those patterns; a recent study by Ellis and Bowen (2017) does precisely this, but its focus is not long-sentenced prisoners per se. A second approach is to investigate 'secondary' desistance, meaning how prisoners self-consciously pursue non-criminal identities. This is more appropriate if the objective is to examine life- and long-sentenced prisoners in general, because research must account for the fact that not all will have espoused a 'criminal' identity.

Put differently: if it is 'imperative' to investigate lifers qua lifers (Kazemian and Travis 2015), then 'primary' desistance, or the causation of lulls and gaps in their offending, is not a sensible topic to research. Yet 'secondary' desistance is extremely relevant even for those who display no signs of prior criminal identity. This is because of stigmatisation: in effect, people convicted of very serious offences are bestowed with 
criminal identity regardless of prior identity and no matter what the context of their offending. In other words, the focus of this study is criminal identity as socially negotiated, and 'desistance' is (partly) an attempt to reckon with imposed stigma. Aptly, in some penal theory (e.g. Duff 2001) stigma is precisely the purpose of punishment: it communicates the unacceptability of condemned actions. Indeed, it has been shown empirically that reckoning with the meaning of the offence is a central adaptive challenge for lifers convicted of murder (Crewe, Hulley, and Wright 2016; Wright, Crewe, and Hulley 2017).

While studies of imprisonment have not tended to be designed within the desistance paradigm, some desistance scholars have written on aspects of imprisonment (Burnett 2006; Burnett and Maruna 2004; Maruna, LeBel, and Lanier 2004; McNeill and Schinkel 2016; Schinkel 2014, 2015), and others have examined how offenders reckon with imposed stigma (e.g. Digard 2010; F.-Dufour and Brassard 2014; Hulley 2016; Waldram 2007). It follows that a focus on secondary desistance might help to understand the development of identity during imprisonment. Desistance theory offers insight into how individuals think about identity and reflect on the social structures around them.

\section{Identity, agency and structure}

The dominant strands in desistance research emphasise the influence of social bonds and human agency. Crudely, for the former, the argument goes that people desist from offending because they have made countervailing commitments to other social roles. Whether consciously made or not, these 'side bets' (e.g. marriage, parenthood, employment) acquire increasing importance to the individual, reducing the attractions of crime by a) altering habitual activities, and b) generating valued relationships which are threatened by continued offending (Laub and Sampson 2003; Sampson and Laub 1993). A second strand in research emphasises the role of human agency: in this version, people deliberately re-evaluate the costs and benefits of criminality, and decide to pursue a different life and a changed identity (e.g. Giordano, Cernkovich, and Rudolph 2002; Maruna 2001; Paternoster and Bushway 2009; Shover 1985). These should not be seen as rival explanations, however; rather, they are two sides of the same coin. Optimism and feelings of agency have been shown to affect the likelihood of successful 
desistance regardless of prior social disadvantage (LeBel et al. 2008). Even so, expressions of hope sometimes belie the multiple social disadvantages desisters face (Maruna 2001).

Human agency and social structure are intimately connected and notoriously challenging to unravel: social action is 'never completely determined', but nor does agency ever 'get "free" of structure' (Emirbayer and Mische 1998:1004). However, attempts to theorise agency's role in desistance differ in their accounts of 'identity', causation, and the interaction of agency and structure. For Giordano et al. (2002:10001003), 'identity' functions retrospectively (by giving narrative coherence to prior cognitive shifts) and prospectively (by 'filtering' future cognition in unfamiliar situations). Implicitly, desistance is impossible without structural opportunities ('hooks for change'), because in their absence, agency has nothing to work with. Non-criminal identities are therefore works perpetually in progress, and desistance is caused by contingent meetings between structural opportunity and the individual's disposition to seize hold of it. By contrast, Paternoster and Bushway (2009) argue that cognitive shifts in the evaluation of criminality are in themselves sufficient evidence of non-criminal identity, and a precondition of desistance, because they result in change to offenders' social and activity preferences. Here, identity change causes desistance, which may be hampered in achieving its goals by structural disadvantage, but is nevertheless still happening.

While both approaches suggest that reflexivity plays a central role in human agency, each relies on an unsatisfactory, polarised conception of identity: people can be 'criminal' and 'non-criminal', or 'social' and 'antisocial'. A synthesis of four theorists' work by Bottoms (2006) offers a richer account of agency and identity, offering a way to think about stigma and its interactions with prior identity. It guides the analysis below and so a summary of the synthesis is therefore in order. First, following Barnes (2000), Bottoms (2006:254-62) argues that an everyday discourse of agency is inseparable from human sociability: it delineates when, how and why individuals can be held accountable for action, and hence when they may be excluded from an 'ordinary moral community' (or 'stigmatised'). For example, blameworthiness is evaluated by reference to concepts like intentionality or recklessness, which are central in both lay and legal discourses of responsibility. Furthermore, the reasons people offer for their actions (or, where action 
has deep temporal roots, 'causal histories of reasons') can, in principle, be matched to explanations of causes in the more formalised terms of scientific discourse. As a result, 'the existence of voluntary actions sensibly described as involving will or agency is not inconsistent with determinism' (Barnes 2000, cited in Bottoms 2006:256). In principle, therefore, it is scientifically (and not merely legally) coherent to explain prisoners' voluntary actions (including offending and desistance) in terms of the reasons they give for them.

Second, following Archer (2000), Bottoms argues that humans make choices against the backdrop of identity - their subjective sense of who they think they are. Identity develops as they adopt, perform, and relinquish social roles, and is socially negotiated: while individuals construct their own subjective accounts of who they are through narration (Presser and Sandberg 2015; Sandberg 2010; Sandberg, Tutenges, and Copes 2015), others read identity in how they balance and fulfil the normative expectations that go with such roles. Emotionality is important in the formation and evaluation of identity, because commitment to roles is 'transvalued' into 'second-order' emotions (Archer 2000:242; cf. Vaughan 2007:400): certain structural opportunities can be felt by individuals to be consistent (or not) with their sense of identity, resulting in sympathetic or antipathetic emotional reactions to social opportunities (Bottoms 2006:264-68). Thus a committed desister might interpret past behaviour as shameful and thus be repelled by opportunities for further offending; but a nascent desister might feel greater ambivalence on both counts, because even a desired change to behaviour or thinking might also threaten valued commitments (such as loyalty to criminal friends) or preclude valued opportunities (such as the chance to make easy money).

Third, following Emirbayer and Mische (1998), Bottoms (2006:268-74) argues that agency has an important temporal dimension: it is not simply choice exercised in the here-and-now, but an iterative interrogation of the past to guide future action. Because much action is habitual, becoming conscious and deliberate only under certain circumstances (Wikström 2014:80-82), conscious deliberation on habitual action plays a central role in desistance. Reflection can be autonomous or sociable (Archer 2003, 2012), but either demands the capacity (and the opportunity) for self-critical judgment; it follows that prisoners who feel unsafe and mistrustful in the prison environment are 
less likely to reflexively evaluate past action (and thus to desist), because they are so preoccupied by day-to-day survival.

Finally, following Kennett (2003), Bottoms argues (2006:274-81) that humans reflexively weigh desired ends against the strength of their ability (or 'will') to achieve them. Those with secure non-criminal identities ('strong wills') may be able to exercise self-control in provocative or tempting situations; but the 'weak-willed' who nonetheless wish to change may avoid provocation and temptation altogether, for example by withdrawing themselves from social roles in prison life which they feel to be inconsistent with who they want to become.

This theoretical picture of how agency figures in desistance is supported by subsequent empirical work (Shapland and Bottoms 2011) However, care is necessary when adapting theory for new purposes. Prisons are highly specific kinds of environment, and their effects on identity are already well-documented.

\section{The effects of long-term imprisonment upon identity}

The subjects of seminal desistance research had often been imprisoned, but these studies did not describe change during imprisonment or say much of the social conditions which influenced it. Prison environments are not generic, and research has long concerned itself with prisoners' behavioural, cognitive and affective adaptations. There is no universal pattern: people bring their own histories, identities and rules of conduct into prison, and the nature of the institution itself also shapes adaptation, because the scope for behaviour (be it compliant, dissenting or resistant) is altered by the character of institutional power (Carrabine 2005; Clemmer 1958; Cohen and Taylor 1972; Crewe 2009, 2011b; Grounds 2005; Haney 2006; Irwin and Cressey 1962; Jacobs 1977; Kruttschnitt, Gartner, and Miller 2000; Liebling and Arnold 2012; Mathiesen 1965; O’Donnell 2014; Schinkel 2014; Sparks, Bottoms, and Hay 1996; Sykes 1958; Ugelvik 2014).

Offence type has not received great attention in prison sociology, but (at least with heavily stigmatised crimes such as murder) is also a significant variable affecting adaptation (Crewe et al. 2016; Wright et al. 2017). The empirical evidence base here is thin, but inferences may be drawn from existing literature on how prisoners adapt to the dual (and often contradictory) norms of the prisoner social world, and those of penal 
power. Taking the first of these, all prisoners must live amongst the prisoner subculture. If it abhors collaboration, hypocrisy, or predation upon the weak, and esteems masculine agency, ambition, autonomy, stoicism and strength (Clemmer 1958; Newton 1994; Sim 1994; Sykes 1958; Sykes and Messinger 1960; Ugelvik 2014, 2015), then it is likely also that this will affect both how burdened lifers feel by their offences, and how they will seek to divest themselves of this burden. This is because offences committed in certain circumstances and against certain victims will be more heavily stigmatised than others, and therefore require different kinds of explanation.

Meanwhile, the expectation of penal power is that prisoners should not merely comply with the requirement to demonstrate reform, but that their compliance should be:

visible, formally recorded and in line with systemic discourses that some [see as being] in conflict with genuine concerns to rehabilitate, and meaningful assessments of truth and risk (Crewe 2006:264; cf. Crewe et al. 2016; Medlicott 2004)

Life-sentenced prisoners may experience this co-option of their autonomy as painfully 'tight', but the appeal of release is so powerful that their resistance will tend to be private and individual, rather than public, organised, or overt (Crewe 2006, 2011a), since they have far more to lose than those determinately sentenced. Compliance with penal power can generate suspicion from other prisoners, but for the most part the appeal of various institutional 'carrots' (e.g. IEP status and consequent relative material comfort, recategorisation, parole) is so powerful that it is not automatically dishonourable, especially if it can be presented as 'self-serving rather than acquiescent', or as the reciprocal manipulation of deceitful 'neo-paternalist' power (Crewe 2009:137-44, 273).

These dual demands make the performance of identity a key concern, whether individual preferences are for subcultural or institutional norms. The implications for inprison desistance are twofold. First, lifers who want to be released must find ways to demonstrate personal change within the systemic discourse of risk reduction, regardless of whether they perceive its conception of change to be meaningful or legitimate. Those whose compliance is instrumental or situational (see Bottoms 2002) are likelier to manifest greater ambivalence, and express private resistance. They are also more likely to see rehabilitative interventions as encroachments on the boundaries of public and private selfhood, which they will guard more carefully (see Genders and Player 
2014:450-52). Second, those whose compliance with the demand to change is normative or habitual (Bottoms 2002) may distance themselves from the prisoner subculture. They may also seek creative ways to reinterpret its underlying principles (such as endurance, toughness, determination, agency) as being consistent with their changed identity.

Since personal identity can largely be read by others from the enactment of social roles (Archer 2000; Bottoms 2006:265-68), we might also expect to see lifers taking up (and avoiding or relinquishing) roles in prison social life which they see as being consistent with who they are. But we should also expect to find evidence of 'frontstage' and 'back-stage' behaviour (Goffman 1961), as well as careful management of emotional presentation (Laws and Crewe 2016; Liebling and Maruna 2005:6-7). Since different environments favour different styles of adaptation and penal cultures differ greatly even within establishments, we should expect considerable variation, because different individuals will have had different 'prison careers' (Toch 1977, 2008). For example, a lifer who has completed long-term therapeutic intervention may experience the sentence very differently to one who has experienced extended periods of fear and distress, or another who has spent long periods in pervasively mistrustful maximumsecurity establishments, or another who wants to change but sees this as a private matter (Crewe, Liebling, and Hulley 2014; Genders and Player 1989, 2010, 2014; Liebling and Arnold 2012; Stevens 2012).

The effects of imprisonment on identity are complex, then, to say the least. Studying in-prison desistance will require attention both to what prisoners say about themselves, but also to the contexts of speech and action.

\section{What would constitute 'in-prison desistance'?}

Based on the literature reviewed above, I frame the pursuit of desisting identity as a matter of deliberate but situated choice, and therefore, following Archer (2000, 2003; cf. Bottoms 2006:262-68), I ask whether prisoners dedicate themselves to 'projects' of change. Agency is inextricable from the ability to 'own' past actions, that is, to coherently present oneself as accountable for them (Barnes 2000; Bottoms 2006:254-62). A concern to change can therefore also be understood as the alignment of subjectivity with what punishment attempts to communicate about the self (Duff 
2001). This leads to the following working definition of lifers' desistance during imprisonment:

1. They claim responsibility for their offending and seek change in ways consistent with this self-presentation;

2. They manage, overcome or neutralise the threat posed to prior identity by the stigma of their offence (see Maruna 2001; Maruna and Copes 2005);

3. They attempt the two preceding points in terms intelligible to both current penal discourse and 'folk theories of mind and behaviour' (Bottoms 2006:255).

Individuals will decline this bargain to the extent that they find its terms incompatible with identity. Periods of impasse in penal 'dead ends' may delay or preclude encounters with 'turning points' (Laub and Sampson 2003): those who resist the reformative demands of the sentence are in dead ends; but so too are those who discover reflexively that they are not who they thought they were. To progress from a dead end one must turn around, but whether this is experienced as orderly retreat or catastrophic rout depends on one's reflexive framing. In such circumstances, agency can remain 'reactive' or become 'productive' (Crewe et al. 2016; Wright et al. 2017); if it is 'reactive' then vague hopes of deliverance may be cherished, but reflexivity and hence agency will be deployed against penal expectation, and individuals will seek to 'master a hard lot with head held high' (Frankl 2008:147), emphasising their past worth rather than their future becoming. This is a form of adaptation and of agency, but is not desistance.

\section{Research questions}

Existing literature on long-term imprisonment frames changing identity mainly in terms of adaptation. Recent findings on the role of the offence in shaping identity (Crewe et al. 2016) can be further developed by using the conceptual lens of desistance, which brings identity and stigma into sharp focus. Conversely, the desistance literature's account of agency and structure can also be enriched by considering these processes within the specific conditions of imprisonment. The following questions deliberately leave room for themes to emerge from empirical data, but set out to root this study in concepts from existing research. These are expected to evolve through encounter with the data: 
- How does 'secondary desistance' occur among life-sentenced prisoners?

- What kinds of events, relationships and opportunities precipitate it?

- To what extent does penal power reinforce and support (and to what extent does it hinder) identity change?

- Under what circumstances do prisoners encounter 'turning points' or 'dead ends'? 


\section{Chapter 3}

\section{Research design and methods}

My decision to investigate 'secondary' desistance meant studying changes in identity, particularly as they related to stigma, or 'spoiled' identity (Goffman 1963). This pointed towards a qualitative and phenomenological study, or one which asks what different participants have (and do not have) in common as they consciously experience a phenomenon, and develops a 'composite description of the essence of [that] experience' (Creswell 2013:76). A focus on how conscious experience influences choice is particularly suitable for the study of desistance, since it seems to involve consciouslyexercised agency. This in turn means attention to agency, identity and reflexivity (Farrall 2005). If understanding agency involves 'tearing down the privacy sign' and accessing people's internal conversations (Archer 2000:317, cited in Bottoms 2006:263), then phenomenology is the appropriate method. In-depth, semi-structured interviews offer insight to the subject's inner world and personal identity (Patton 2015). They also permit the use of both deductive and inductive reasoning, because prior concepts structure the interview, but themes emerging during interviews can also be pursued (Layder 1998).

Although desistance theory sees change as an iterative long-term process, a longitudinal design was unfeasible for this study. Thus the design is cross-sectional, enabling in-depth comparison between cases, but not certainty regarding causation. The intention was to purposively sample prisoners with a 'criminal identity' and to examine how imprisonment had affected this. This meant that, to be eligible, participants should:

- have two or more convictions prior to the index offence

- be serving sentences of at least ten years;

- have been in prison for a minimum of two years since sentencing;

- not be on recall. ${ }^{1}$

I also intended to sample prisoners varying widely on age and the proportion of their sentences served, since both desistance and adaptation to imprisonment take place over long timescales (Crewe et al. 2016; Irwin 2009; Laub et al. 1998).

\footnotetext{
${ }^{1}$ See Appendix 2 for further details.
} 


\section{Fieldwork site and access}

HMP Gartree was suggested by my supervisor and by staff from NOMS, on the basis that many prisoners among its stable long-term population would be eligible. All 700 adult men at Gartree serve indeterminate sentences (IMB 2017); the prison's role is to help them 'come to terms with their sentence and to make progress in [...] reducing their risks' (HMIP 2014:5). Its residential units include one dedicated to prisoners aged over 50, as well as the Gartree Therapeutic Community (GTC). Risk reduction is pursued through accredited offending behaviour programmes (OBPs), of which the GTC is one. Vocational training and other education is provided, but because educational budgets currently concentrate on the later sentence stages (Skills Funding Agency 2015), education at the prison has been described as 'narrow', with 'mundan[e]' workshop activities and high levels of unemployment (HMIP 2014:5). Nevertheless, its long-term population, low population churn, and positive staff-prisoner relationships contribute to an overall atmosphere which compares favourably with similar prisons (ibid.; IMB 2017). I carried keys and moved around independently during fieldwork, but received practical support from the prison's Psychology team. Fieldwork took place over ten days in April and May 2017.

\section{The sample}

The sample comprised eighteen men (see Appendix 1). The prison preferred initial approaches to take place before fieldwork, and asked me to select cases from an anonymised list containing eligible individuals' ages, ethnicities and sentence characteristics. Since associations have been shown between desistance and feelings of hope (LeBel et al. 2008), and since O'Donnell (2014:201-5) argues that sentence and life stage affect the viability of hope (see also Crewe et al. 2016), I cleaned, ranked and sorted data in the anonymised list into quartiles, according to a modified version of O'Donnell's Pain Quotient (PQ, see Appendix 3). Each quartile was then ranked and further subdivided into quartiles on age when sentenced. In random order, prisoners from each subdivision were then sent information sheets and expression-of-interest forms, with the intention being to interview at least one from each subdivision. ${ }^{2}$

\footnotetext{
${ }^{2}$ At this stage, the prison recorded eight refusals. Thirteen expressions of interest all led to an interview.
} 
However, it became clear during fieldwork that the anonymised list included many ineligible prisoners with no prior convictions. Staff absences made it impossible to revisit the list and work out what had gone awry. Rather than call off interviews I was not certain I could replace, I fulfilled those already scheduled and approached further participants in person, trying to fill gaps in the subdivisions and to prioritise those with prior convictions. $^{3}$

Table 1: Frequency distribution of the sample $(n=18)$ by $P Q$ rank and age when sentenced

\begin{tabular}{c|c|c|ccc}
\hline \multicolumn{1}{c}{} & \multicolumn{5}{c}{ PQ rank quartiles } \\
\cline { 2 - 6 } Age-when- & 1 & 1 & 2 & 3 & 4 \\
sentenced & 2 & 1 & 2 & 0 & 0 \\
quartiles & 3 & 1 & 1 & 1 & 1 \\
& 4 & 1 & 3 & 1 & 1 \\
& 1 & 0 & 2 & 2 \\
\hline
\end{tabular}

Table 2: Descriptive statistics for the sample $(n=18)$ and the eligible population $(n=489)$

\begin{tabular}{lll}
\hline & Sample & Population \\
\hline $\begin{array}{l}\text { Age } \\
\text { Mean (s.d.) } \\
\text { when sentenced: }\end{array}$ & $38.8(12.1)$ & $40.8(12.0)$ \\
$\quad$ Mean (s.d.) & $31.7(11.7)$ & $33.9(12.0)$ \\
\hline $\begin{array}{l}\text { O'Donnell's PQ } \\
\text { Mean (s.d.) }\end{array}$ & $10.8(6.4)$ & $10.8(5.9)$ \\
\hline $\begin{array}{l}\text { Sentence type } \\
\text { Life }\end{array}$ & $100 \%(18)$ & $98 \%(478)$ \\
IPP & - & $2 \%(11)$ \\
Ethnicity & & $59 \%(288)$ \\
White British & $61 \%(11)$ & $35 \%(172)$ \\
$\quad$ BAME \\
$\quad$ of which: \\
$\quad$ White non-British \\
$\quad$ Black or Black British & $39 \%(7)$ & $5 \%(24)$ \\
$\quad$ Asian or Asian British & $22 \%(4)$ & $13 \%(64)$ \\
$\quad$ Mixed & - & $12 \%(60)$ \\
$\quad$ Other & $6 \%(1)$ & $1 \%(5)$ \\
$\quad$ Not stated/missing & - & $6 \%(29)$ \\
\hline
\end{tabular}

Though all participants were serving mandatory life sentences for murder (and some had concurrent convictions), half ( $n=9$ ) had no prior convictions, and only five had two or more as originally envisaged. The eventual sample nearly attained the hoped-for

\footnotetext{
${ }^{3}$ Only two of the resulting five interviewees had a single prior conviction each.
} 
spread of age and sentence stages (see Table 1), and broadly represented the population it drew on, except in the distribution of its ethnic minority members (see Table 2). But since it did not sample the population envisaged, the cases were more dissimilar than anticipated. During fieldwork, the impression grew that subcultural norms discouraged participation. When I visited the wings to confirm an interview with (especially younger) prisoners who had returned a paper form expressing interest, they behaved with reserve, 'fronting' nonchalance or reluctance in front of other prisoners, only to express interest in the study in the privacy of the interview room (cf. Crewe, Warr, et al. 2014; Laws and Crewe 2016). It is impossible to quantify resulting gaps in the sample precisely.

\section{Data collection, analysis, and classification}

All participants consented to my recording the interview; these averaged 93 minutes in length, ranging from 42 to 145 . Eleven were held in rooms booked for the purpose. Seven were held elsewhere for pragmatic reasons; staff were informed. With three exceptions, interviews were private and uninterrupted; interruptions were momentary. I scheduled one interview per three-hour morning or afternoon session so there would be ample opportunity for small talk and questions beforehand and afterwards. A good rapport developed in most cases, but even so, some interviews felt more conversational than others. My departures from the interview schedules (Appendix 4) pushed for clarification or explored contradictions and ambiguities, probes which I framed in terms of ignorance, not mistrust. I freely altered the sequencing of questions but tried not to pursue digressions far, though I relaxed my instinct to control the conversation where the interviewee spoke according to apparent need. ${ }^{4}$ Despite such flexibility, I did not omit questions without good reason (see below). At the end, interviewees were asked to provide sentence and demographic data (see Appendix 7) to triangulate information from the prison and facilitate case comparisons. It is possible that because I was a man interviewing men, respondents drew upon discourses of masculinity which were perceived to offer common reference points for details of their life and offences (cf. Broom, Hand, and Tovey 2009; Williams and Heikes 1993).

\footnotetext{
${ }^{4}$ For example, Martin spoke for twenty minutes without interruption before I could raise the matter of the consent form. Only after I started recording did he visibly relax; he revisited much of what he had said in response to my questions.
} 
Recordings were transcribed verbatim, with annotations from my contemporaneous notes on 'feel' and emotional tone. Transcripts totalling 222,295 words were coded in NVivo, to an initial list of nodes drawn from my reading. As I proceeded, I combined nodes, discarded others, and added new ones which emerged from the data. This was an iterative process guided by Layder's adaptive approach $(1998,2013)$, which encourages a combination of deductive and inductive thinking. As the analysis developed, I experimented with conceptual groupings of cases, crossreferring my developing classification against a colour-coded table of demographic and sentence data. This process of comparison continued well into the write-up, until I was content that my classification was the best possible fit.

Because the eventual sample varied not only on age and sentence stage (which was intended), but also on background and prior identity (which was not), the phenomenon under study (Creswell 2013) was how lifers in general negotiated with the imposed stigma of a murder conviction. The resulting classification has elements of both taxonomy and typology (see Smith 2002:381-82). I defined in-prison desistance (see page 11) and clustered cases based on how their properties matched the description. This is a taxonomic method. Nevertheless, the analysis classifies styles of agency, not types of prisoner. In this, it resembles a typology, in that the dimensions of classification represent abstract concepts, not specific empirical characteristics. Typologies have drawbacks, including:

'categories that are neither exhaustive nor mutually exclusive, are often based on arbitrary or ad hoc criteria, are descriptive rather than explanatory or predictive, and are frequently subject to the problem of reification.' (Smith 2002:381)

Some of these drawbacks were mitigated: the categories originated in established empirical findings about desistance, reducing the risk of reification; and they are not merely descriptive but help to explain adaptations to imprisonment. Nevertheless, unlike a thoroughbred taxonomy, the styles of agency it describes should not be read as necessarily definitive, exhaustive, or mutually exclusive. The study was small-scale, the sample was diverse in unforeseen ways, and some taxonomic clusters included only two or three cases. This meant that theoretical saturation (Marshall 1996) could not be assured. Furthermore, however accurately the classification represents individual cases, their position in it will not be fixed in it over time, since adaptive and agentic styles also 
change over time (thus cf. Crewe 2009; Crewe et al. 2016; Giordano et al. 2002; Maruna 2001; O’Donnell 2014).

If anything, the classification presented below more closely resembles a typology than a taxonomy, but a larger sample would have resulted in more confidence that the types of agency it describes could be freed from their descriptive ties to clusters of specific cases. Its hybridity results both from the unexpected variation in the sample, and from an adaptive approach to theory (see Layder 1998, 2013), with its cycles of deductive and inductive reasoning.

\section{Ethical safeguards}

My initial thinking was informed by the British Society of Criminology's (2015) Statement of Ethics, as well as practical reflection on my past professional work in prisons. The three primary concerns were: informed consent; confidentiality and anonymity; and interviewee welfare. To achieve the first, all potential participants received an information sheet (Appendix 5). Key points were discussed in person, participants could ask questions, and were invited to sign a consent form (Appendix 6) before the interview proper began. They were also offered the chance to withdraw before a specified date. My informal conversations with prison staff and non-sampled prisoners, though illuminating, were not subject to these arrangements and are not used in my analysis. Anonymity and confidentiality were bounded by defined limits. This seemed to encourage openness. Pseudonyms were stored separately from real names, recordings were moved daily from the recorder to an encrypted device, potentially identifying details were removed from transcripts and redacted from scans, and paper records were kept securely. All data will be destroyed securely after specified dates. Regarding welfare, I made it clear that interviewees could take breaks or decline to answer questions, although none did either. After each interview, I asked whether any part had been difficult or distressing. Despite segments of some interviews being charged by emotions such as anger or shame, no interviewee answered affirmatively. However, two expressed anxiety because the information sheet had trailed the remote possibility of upsetting questions. At these and other moments where the interviewee appeared uncomfortable, I tried to offer reassurance and reminders of the safeguards. 


\section{Grey areas}

Despite these measures, the research generated ambiguous situations meriting further discussion. This was a study of change in prison, not of murder per se; my questions were directed at the former. Even so, prior research with similar populations suggests that feelings about the offence can structure attitudes to change, because lifers grapple with the meaning of having taken life even if they dispute the precise narrative of events endorsed by their trial (Crewe et al. 2016; Irwin 2009). Attempts to reduce culpability may, at least in part, be read as reclamations of moral status: a 'sad tale' invites forgiveness for grave but irreversible wrongdoing (Goffman 1961, 1963; Maruna 2001:143-45; see also Maruna and Copes 2005). Some see this as objectionable: the aim of a punishment, after all, is to make the offender 'appreciate the wrongness of [his] action, and not simply to recognise the prudential reasons to follow the law' (Brownlee 2011:54; see also Duff 2001). However, the amount and style of responsibility expected will never achieve universal assent, depends on wider cultural and political context, is affected by the perceived legitimacy of the sentence, and changes over time (Cavadino and Dignan 2006; Maruna 2001; Schinkel 2014).

This study suggests that lifers do indeed experience complex and contradictory emotions concerning their offences. These might include unresolved regret, grief and guilt; incomprehension of past actions; anger and frustration concerning their penal predicament; a deep longing to progress towards release; and a yearning to be considered viable future members of an 'ordinary moral community'. Such feelings greatly complicate the terms on which reform can be understood as real. I had to think carefully about whether (and how) to ask about the circumstances of the offence. I anticipated (correctly) that some interviewees might dispute the official account of their culpability. I offered no challenge when this happened; I had no basis to do so and it would, in any case, have undermined the rest of the interview. Methodologically, it was also important not to align myself too closely with penal discourse (see Medlicott 2004). Bearing this in mind, I asked about life before prison and change experienced during the sentence, but left interviewees to volunteer information about the offence. If they did, I took it as evidence that the offence was important to their own concerns as changing people, and vice versa. In general, I took statements about the past primarily as evidence of how interviewees felt now about their convictions and sentences, and not 
necessarily as a 'true' account of what actually happened. Accounts of the past are never facsimiles; people narrate them to serve present needs, and narration reconstitutes past experience in ways the narrator may experience to be true (Presser and Sandberg 2015; Sandberg 2010); it was unfeasible (and unnecessary within the terms of this study) to test their factual status.

Lifers are under heavy pressure to come to narrative terms with the 'official record' of their offending, sometimes experiencing this as an assault of sorts. Where I sensed hesitancy or resistance to a line of questioning, I persisted until I seemed to encroach upon an important belief or commitment, or was at risk of provoking distress. For example, after Desmond said he had issued 'do not resuscitate' instructions during a recent hospital visit, I realised that he probably expected to die in prison. I omitted my next question (about the future) as gratuitous and unkind. Richard, meanwhile, interpreted my probing of his beliefs about the purpose of imprisonment as a surreptitious invitation to recant earlier statements about its futility:

BJ: So for you, then, the point of this place is to serve the needs of people outside?

Richard: Again, again! You want me to say rehabilitation, stuff like that!

BJ: I don't want you to say anything...

Richard: Well, I just did. I just did. I've never known anybody to leave prison rehabilitated.

It was clearly time to move on, and we did.

What I was told about offences suggested that there are, for the perpetrators at least, different degrees of murder: the circumstances appeared to affect their encumbrance by shame. As I transcribed, this left me feeling that not asking directly about the offence had been mistaken. Because gaps in what I knew hampered comparison, I searched the web for media coverage of the participants' convictions, using what I found to contextualise interview data. ${ }^{5}$ This pragmatic response to an unforeseen research problem made me uneasy: it seemed ill-matched with the voluntarism and trust tacitly implied by my interview stance.

\footnotetext{
${ }^{5}$ The cases had received varying amounts of coverage. In seventeen, I found at least information about the basic circumstances of the offence. In one, I found nothing.
} 
Ethical judgements in prisons research are fine, contextual, and imperfect (Liebling 2001). I have presented what I found (and was told) about index offences in general terms, preserving anonymity. I believe this fulfils my obligations to them, and disagree that the interview stance was collusive or the searches unethical. However, I recognise such objections are tenable on some readings of research ethics. 


\section{Chapter 4}

\section{Findings}

I begin by describing two groups of prisoners who, according to my definition, were in 'dead ends'. The first had a style of agency which I describe as 'defensive', in that they gave reasons for action on their own terms, minimising culpability. A smaller group's agency was 'fractured', in that they could not give morally coherent reasons for their behaviour. I aim to describe how these men had arrived at 'dead ends', and then to identify what inhibited them from turning around. I then describe two further groups who had encountered 'turning points'. One group's agency was 'corrective', in that it aimed to learn from past mistakes and prepare for a better future; and the second employed 'redemptive' agency, which hoped to atone for past behaviour by integrating it with a new, penitent identity. I seek to explain how and why these men had come to embrace the idea of change.

For each group, my analysis begins by describing how its members cohered, in terms of their demographic and sentence characteristics. ${ }^{6}$ I then describe their characteristic ways of presenting themselves as responsible (or not) for their offences, and how this influenced their attitudes to change. I highlight how their accounts were shaped by prior identity and the circumstances of the offence, and also describe the reflexive stance of each group towards the social world of the prison. The focus is on attitudes to change and to rehabilitative intervention, but also on how each group saw the prison environment more generally.

Each section ends by discussing its findings on dead ends and turning points. Throughout the analysis I attribute all quotes to a pseudonymous individual, except where I judge they might be identifiable.

\footnotetext{
${ }^{6}$ Selected details are presented in this chapter; full details for the individual cases and the groups classified can be found in Appendix 1.
} 


\section{Dead ends}

\section{'Defensive' agency}

As a group, Desmond, James, Joe, Luke, Pete, Richard, and Thomas had the longest tariffs (group mean 21.1 years, sample mean 18.1). Six had served less than half, and five less than a third, of their sentences. These seven included all six from the sample who said they were not guilty as charged; the other was appealing his sentence because he said the judge had not accounted for mitigating circumstances.

\section{External and internal threats}

Defensive agency sought to control twin moral threats generated by the prison environment and the offence. The degree to which each was emphasised depended on the extent to which the norms of the subculture offered viable protection. James, Richard and Desmond had all been in prison before. They said less about dangers in the environment than those who had not been imprisoned before, though descriptions by James and Richard conjured images of them as stoical, tough and self-sufficient even as the dangerous experiences they described evoked fear in me. Their nonchalance may have been a form of 'fronting' (Crewe, Warr, et al. 2014; Laws and Crewe 2016).

By contrast, Joe, Luke, Pete, and Thomas, had never previously been in trouble with the law, and distanced themselves from subcultural norms. While Thomas's hyperbole regarding other prisoners ('unhinged maniacs') was not widespread, all five implied moral non-equivalence with such people, suggesting an underlying defensiveness against criminal identity itself. These men also spoke of the prison authorities in less cynical terms than those who had served time before, implying that in principle the prison had a right to its methods:

'[O]bviously something has gone wrong for anybody to have committed any crime. And so [prison] should be used as an opportunity to make things better.' (Joe)

They highlighted previously unblemished character (possibly appealing to perceived shared values in me), and emphasised their great difficulties adjusting during the early stages of the sentence. Terms like 'swamped' (Joe) and 'overwhelming' (Pete) suggested 'entry shock' (Wright et al. 2017), a headlong plunge into an unfamiliar and potentially contaminating world. 


\section{Attitudes to the offence}

Regardless of how they presented the environment, these men preferred to hold the sentence's demand for change (Duff 2001) at a distance. Some did this by disputing their culpability, though only one asserted complete innocence: 'I'm Joint Enterprise, so I didn't do it. This is just... wrong people, wrong place, wrong time. Wrong whatever' ${ }^{7}$ For others, the viability of neutralisation and minimisation (Maruna and Copes 2005) varied. Richard and James, both of whom had multiple convictions and had killed other men in arguments, confidently described their offences as combat between consenting equals which had regrettably got out of hand. Alternatively, they claimed self-defence. Such assertions were less tenable for those whose victims had been women, vulnerable (e.g. elderly) men, family members, or (in one case) a child, undermining their masculinity in the man's world of the prison (Newton 1994). They said little or nothing of the offence in the interview. It was instead presented as a private matter (as though inherently more shameful) though thoughts of it may have disrupted smooth selfpresentation:

\section{I'm not here through my own fault, but I'm not going into that.' (Desmond) \\ 'I know I'm not a bad person. I have had some issues in my life [...] But I've always managed to cope with them [...] I don't really want to go into that too much. I don't think it affects me too much [eight-second pause] Sorry, what was the question again?' (Pete)}

The sole exception was a man whose narrative betrayed its precariousness precisely by its polish and precision:

I've gone over it hundreds of times. There is a split second where she hit me, I lashed out, and then exactly three seconds that I don't remember'

This man denied altogether the extremely stigmatised offence for which he had a concurrent conviction, and said he would not discuss it in any context where other prisoners were present. Like all the other defensive agents, he sought to control not to confront the past; but he also tried to 'pass' (Goffman 1963:109; Shover 1985:68-70) as someone less stigmatised. Explaining this, he said that he had to be 'a bit like a chameleon' to evade 'predators'.

\footnotetext{
${ }^{7}$ Joint Enterprise has been identified as a source of considerable illegitimacy in sentencing (see Crewe, Liebling, Padfield, et al. 2014).
} 
Censoring the past, controlling the present, suppressing the future

The defensive stance limited the moral worth that could be derived from changed future identity. Invocations of past non-criminal achievement were common in this group, to an extent unusual in the sample as a whole:

'I just wanted to work hard, I had a lovely daughter - I still have a lovely daughter and I wanted to [support her]. I was never [a criminal sort of person]. Which is a little bit of a conflict for me, since I am here. But yeah, just... [sigh] I can't say any more than that, really.' (Pete)

Even those with lengthy criminal records characterised themselves thus; not without blemish, but as 'a lovable rogue' who had already changed for the better (Richard), or:

'an honest character, very loyal, passionate, outspoken, opinionated ... um, [long pause] with... with quite a few elements of danger... [long pause] I'm not a dangerous person, though, but [...] I like to be on the edge, you know?' (James)

The conversational incongruity of lifers asserting their harmlessness required some form of balance, evident in Pete's reference to 'conflict', Richard's use of juxtaposition, and James's clarification of 'danger'. This acknowledged the ever-presence of imposed stigma, regardless of self-presentation. Not to acknowledge any 'spoiling' of identity (Goffman 1963) would belie the fact that we were talking at Gartree.

Joe crisply captured an intention shared by all, regardless of prior criminality: 'you have to make an effort to hold onto whatever you consider to be yourself'. This was matched by a characteristic defensive framing of support from outside as an endorsement of enduring worth:

'The other month, [my brother's kids] chose to come and see me, rather than go with their mother to the fair!' (Richard)

Support from outside buttressed identity against stigma, but it was striking how many described it in terms of loyalty. Thomas's assertion, that a small number of supporters were 'people who actually know me' and 'actually believe me' was representative. Even so, Joe's description suggested submerged feelings that it might not be deserved:

'[their loyalty] is amazing. If I allow myself to think about it for too long, it can actually get me quite upset'.

But exploring such feelings in an unsympathetic environment threatened repercussions, and only one man's account of the offence evoked any doubt as to his culpability. As a 
result, contact with the world outside could be burdensome, because 'staying strong' (Richard) meant concealing the twin struggles against the environment and the self. Prison life (and the offence) were not for outside consumption and awareness of the sentence's effect on loved ones meant that attempts to censor and 'put away' (James) thoughts of the past leaked. Masculine pride at having been a hard-working family man, for example, was brittle and double-edged, because imprisonment precluded full performance of its social expectations (Archer 2003) and rendered this identity implausible. For some, restriction (or loss) of contact with children had been 'crushing' (Pete), and the inability to be there for elderly parents already burdened by their imprisonment was a recurring and humiliating theme:

'[My parents] don't know that I was assaulted. They know that I hit my head [while I was fixing something]. That's all they need to know. I don't want to make it any fucking worse than I already have.' (Thomas)

A censored past therefore offered thin consolation, but defensive agency also sought to control the present and suppress the future. Most men in the group were relatively early in the sentence, having at most 'one eye subconsciously on the future' (James). Even those pursuing deliverance via legal appeal equivocated about the prospect:

'If your mind is out of the door too much, then you don't settle [...] The best-case scenario would be a few years taken off [the sentence], and it would be perhaps a decade [...] before that made any difference, anyway. So it doesn't feel very real.' (Joe)

If human agency is 'a temporally embedded process of social engagement' (Emirbayer and Mische 1998:963), and the early stages of very long sentences resemble a form of 'stagnation' in which life is 'on hold' (Crewe et al. 2016:529), then defensive agency sealed off the temporal threats of an undifferentiated, abstract future, a dangerous and unpredictable present, and an inaccessible and potentially traumatic or shameful past. Its virtue was that it tamed the present, and sought 'niches' (Toch 1977) of positive experience. One of the first-time prisoners had recently moved from the 'chaotic' main wings of the prison to the 'calm', 'lovely', 'relaxed' atmosphere of the over-50s wing:

'It's a funny thing to say, but I'm sort of enjoying prison! And I've never enjoyed it before [...] [Things used to be] quite bleak, I didn't think I would be able to [survive] the 
sentence. But I think being down here [...] has changed my opinion of the future, it really has.'

This quote shows that 'projective' reflection — 'the creative reconfigurat[ion of] received structures of thought and action [...] in relation to hopes, fears and desires' (Emirbayer and Mische 1998:971) - becomes possible when people are not preoccupied by day-to-day survival, with potentially transformative results. It was more typical, though, for defensive agency to render the sentence existentially meaningless:

BJ: Do you think forward to life after prison?

James: I try not to, no. I'm aware of it, but, you know... I'm in here, this is just here and now [...] I try not to think about, or worry about, things I don't have any control over, because you just worry yourself over nothing. So I just... [pause] just go from day to day, really.

Without the opportunity for projective reflection, narratives of change among these men typically lacked moral content, or were free from volition:

'[M]oney was always a bit of a problem for me on the out [...] I know we don't earn much here, but we actually have to be very careful. So in that respect l've actually improved, definitely, as a person.' (Pete)

I'm the same in a lot of ways, a little bit different in a few other ways, I suppose. I dunno where it comes from.' (James)

\section{Compliance with rehabilitative intervention: softening the defensive stance}

Because their offences and their reflexivity were cloaked in privacy, it was hard to discern how (or if) the defensive agents thought about change on their own terms. It appeared, in general, that they felt it was none of anyone else's business. Even so, they understood that the sentence required them to demonstrate change in the terms of penal discourse (Crewe 2006). At least on this level, change was experienced as an imposition, hassling them away from more consoling reflexive practices. This generated ambivalence for all, sullen resistance from some, and indignation from a couple. Except for appellants, though, internal stalemate over the offence did not generally result in flat non-engagement with the prison's offending behaviour programmes (OBPs). Joe and Pete reluctantly acknowledged that the defensive stance would need to soften eventually, but also held it at a distance: 
'If I was to jump on certain courses now, [by the time I am] getting towards the end of my sentence, those courses will be obsolete. And so I will probably have to repeat [them].' (Joe)

'I just don't believe that I should be doing any courses. [But] I think I'm probably planning on doing TSP [Thinking Skills Programme], because it's thinking skills, and I probably didn't think as much as I should have. If you've got a big sentence, there's no point in doing all of the thinking skills near the beginning [...] because you might forget. And it doesn't really mean anything.' (Pete)

Both quotes - and especially Pete's muddled rationale for engaging with TSP suggest a kind of rehabilitative procrastination, suggesting that change was an extrinsic demand. References to OBPs as 'hoop-jumping' (Joe), 'box-ticking' (Richard) or 'nonsense, just a pile of shit' (James) suggested far greater resistance, and showed that these men struggled to frame meaningful change in the terms of risk reduction. Those with prior convictions tended to vehemently deny the rehabilitative promise of OBPs:

'When people get out of prison, and they go for a job, and the bloke turns around to you, and he says "well, what qualifications have you got?" [...] [Then] you say, "well, I ain't got no qualifications, but I've done Resolve, and I've got Enhanced Thinking Skills". And he goes, "Yeah, nice one. See you later."' (James)

Even so, James was sure that in time, 'they're gonna ask me to do something along the lines of offending behaviour, and I'll do it'. These attitudes echo typologies of prison compliance: defensive participation in OBPs could be 'instrumental' in the sense that it hoped to obtain sentence progression, and 'situational' in that it required the performance of a certain self in the classroom (Bottoms 2002). Richard was an appellant, and the selfhood he presented was more defiant:

'There is no way I'm going to admit to this case. So you can do whatever you want with me, even if I lose my appeals [...] [Can] you imagine, after [...] twenty-five years, they will not release me because I haven't done my... [makes dismissive noise] How can you hold someone who's done their time, for not doing an exam? That's the rebel in me, there.' (Richard)

This was a particularly sharp statement of how defensive agency conceptualised the sentence: it was not a summons to the 'invitational edge' (Maruna 2001), but (if anything) a debt, paid in the coin of hard time endured like a man:

"The press and the tabloids have us all down as [scary voice] "cold-hearted killers" when [a lot of the people in here] just made that one big mistake. And they are paying for it, but that doesn't mean they are defined by it.' (James) 
Shouldering stigma (for James, being 'defined by' the offence) meant colonisation by alien values, adding insult to injury. The 'neo-paternalist' (Crewe 2011b) rubric under which courses were offered could seem dishonest and infantilising, requiring an unfelt penitent performance:

'They say, "oh, we think you might benefit from doing PIPE." Really, what they're saying is, "we want you to do PIPE. You've got to do PIPE [...] because you won't be going to Ccat otherwise." [...] Or, "How can I do a violence programme? I've got no previous." Again: "oh, we think you'll benefit from it." It's just Catch-22. Basically, I've got to do it.' (Luke)

Richard and James both reported a practice described by many other prisoners in the sample, namely attending OBPs, 'telling them what they want to hear', and if possible paying other prisoners to 'do the homework'. This was offered as evidence that the courses were useless, and emphasised that self-interested engagement could be presented as crafty subterfuge (Crewe 2006). ${ }^{8}$ Meanwhile, defensive agents who were less committed to subcultural norms expressed little anger at the co-option of their autonomy; they saw the prison's role as legitimate (if unwelcome) and were more likely to procrastinate, characterising a reckoning with the offence as (for now, at least) not their priority. As a strategy, procrastination held a strong appeal during the early years of long sentences.

A final contrast can be made with Desmond. In his 70s, in poor health, and having exhausted his options for legal appeal, his concerns and goals did not include release. The prison's hold over his cognition (if not his body) was therefore broken. He expressed no ambivalence or anger, because self-reformation was of no relevance. His powers of reflection were used to redefine the meaning of his predicament, and to bypass the pains of greater expectation:

'Fair enough, we shouldn't be kept in the cell and beat up regular, I don't mean that. But we've got no rights. We gave up all our rights when we come here, I think.' (Desmond)

This forbearance was puzzling when juxtaposed with Desmond's belief that the offence had not been his fault, but unlike others, his insistence on privacy regarding the offence

\footnotetext{
${ }^{8}$ Similar shenanigans were described by many in the sample, but 'corrective' and 'redemptive' agents typically offered them as evidence of the hypocrisy and dubious character of those who engaged in them. They implied that their own compliance was a different form of manly endurance: swallowing pride and getting on with the job in hand.
} 
was tenable. Desmond's ultimate concern (Archer 2003) was to reconcile himself to ending his life in prison, and his defensiveness was thus a last stand on diminished territory. The prison's power to break defensive resolve depended on its most tempting 'carrot' (Crewe 2006): the prospect of release. Like the others, Desmond pursued meaning he defined for himself (see Frankl 2008), but unlike them his defence was impregnable. 


\section{'Fractured' agency}

Two men (Billy and Danny) readily admitted guilt, but their accounts of their offences implied that it would have been impossible for them to have done otherwise. Their accounts thus offered 'causes', not 'reasons'; only the latter is consistent with a language of agency (see Barnes 2000; Bottoms 2006:254-62). Their agency was 'fractured', in the sense that they apparently wished to take responsibility, but could not do so in a socially intelligible way.

They were of average age when sentenced (mean 31.0 years, sample mean 31.7 years) but neither had been convicted before. Their tariffs were comparatively light (mean 12.5 years, sample mean 18.1). Yet they appeared mostly to have experienced the sentence as meaningless, and neither could see any legitimate purpose to imprisonment:

'It's a sweat box. It's a storage unit for people. It's purely political. There is no true, solid, real, rehabilitation.' (Billy)

'I don't personally see any purpose to imprisonment. [People here] have just made, a general mistake... And they are still being highly punished, and it should not be.' (Danny)

\section{Unintelligible accounting for the offence}

Unlike all others in the sample, the reasons Billy and Danny offered for their offences neither minimised blame nor accepted it with a regretful story of mitigation. Instead, they denied agency altogether by implying their behaviour was caused, without agentic reason. Danny drew on notions of fate:

'[B]oth of us, really, were heading for a deathbed from drink, and fortune intervened and went, "right, one of you's not, and one of you [is...]"

His victim was 'the person who died', and the offence was 'the thing that happened'; the intransitive verbs removed him from the picture. His self-description as someone without 'an aggressive bone in my body' offered no balancing acknowledgement of where the conversation took place, and his account of life beforehand contained confusing inconsistencies: as a 'family man' his relationship with his children had been 'brilliant', but he had also abandoned them to shield them from the consequences of his alcoholism and homelessness. His children had been 'there for [him] 24/7, unconditionally'. This reversed the normal role expectations of parenthood: he could not 'define who [he was] or what [he] would need to become' (Archer 
2003:304) to fulfil the social identity of fatherhood, and was therefore a 'fractured reflexive'. He implied passivity, victimhood, and propulsion by forces beyond his control; he lacked a 'language of agency' (Maruna 2001:77) and his offence was framed by a 'condemnation script'.

Billy also declared he was guilty as charged. His inability to untangle cycles of physical and sexual abuse beginning in childhood ('I died around eight years old') hampered coherent accounting for actions he nevertheless claimed as his own. He framed the murder of 'one of the few people who actually cared for me' as a cry for help, having failed to obtain assistance through other channels. He felt bitter about what was available in prison ('I thought that prisoners got help'), but had repeatedly found himself unable to sustain participation in TCs, in part because he felt completely unable to speak of his confused sexuality and his past as a sex worker. His circumstances and background were uniquely painful and complex, and he said only one-to-one psychotherapy offered a way to confront them. Like Danny, he could not identify a 'real me' or 'core self' around which to build a desistance narrative (e.g. Farrall 2005; Stevens 2012): the frightening disorder of his life resisted such narrative tidying:

'the real me was never there [...] I have tried to write a film [about it], actually. But it's impossible.'

As a result, he felt paralysed and helpless. Reflection on his past and what it meant for the present simply intensified the disorientation and distress he already felt, leading to inaction - suggesting Billy too was a fractured reflexive.

\section{Coping, but barely}

Unable to mobilise the defences of subcultural status or prior conventional achievement, these men functioned outwardly in the prison, coping through a combination of self-imposed social isolation, self-harm and, in one case, drug use. They both avoided public areas and interactions with staff when possible, and participated in few activities, generally favouring those which offered techniques of self-management, such as meditation. Both described the environment as threatening and the cell as a refuge. Outward compliance masked roiling anger about the tribulations of 'getting the right help' (both), and led to a procrastinating search for alternatives: Billy pursued private quasi-therapeutic conversations with TC graduates, though described these too 
as upsetting if they challenged his sense of himself as a helpless victim of circumstance. My inference was that, as compliant individuals who coped privately, they were perceived by the prison as low-risk and hence as low priorities for interventions which might have helped them more directly. 


\section{Discussion}

Recent research (Crewe et al. 2016:526-28; Wright et al. 2017) describes the adaptations of life-sentenced prisoners early in the sentence: finding themselves in an 'unexpected and extreme' situation and ripped away from 'the behavioural repertoire set out by their past', they are initially able only to react. The findings presented here about prisoners in 'dead ends' somewhat modify this picture. Crewe et al. (2016) conclude that lifers in the early stages of imprisonment resemble 'fractured reflexives' (Archer 2003) in their leanings towards passivity and drift. Here, however, true 'fractured' reflexivity was located elsewhere, not among those early in the sentence, but those who, lacking a 'language of agency', could not offer socially intelligible accounts of responsibility for their actions. For others not (yet) fully adjusted to the sentence, I have chosen the label 'defensive' agency (rather than Crewe et al.'s 'reactive'), reflecting my focus on imposed stigma rather than adaptation per se. Their response to the conviction was not entirely reactive, but evoked a kind of sustained (and sustaining) ambivalence. Insofar as their reflections on the offence were expressed in the interview, they recognised the intersubjective context of human agency, in that the conviction's demand for a coherent 'causal history of reasons' was experienced as legitimate (Barnes 2000; Bottoms 2006:254-62). What was not was the demand that reasons should be given in someone else's terms. Defensive agency narrated 'reasons' for offending which skirted penal and psychological discourse, and demanded the listener's normative assent to the narrator's normative terms. Defensive agents refused to delve deeper for understanding, recognising wrongdoing but limiting culpability's claim on the self. Fractured agency, by contrast, lacked the reflexive resources to 'own' even a less culpable role in the conviction; its contention was not that 'you would have done the same in the circumstances', but that 'I am helpless in all circumstances'.

Some in 'dead ends' had experienced great difficulty in adjusting; unlike in Crewe et al.'s study, this small but broader sample included some sentenced after the age of 25 , in mature adulthood, when cognitive flexibility is less than at a young age. Youthful naivety offered no defence, and they had lost far more than youthful potential to the sentence. They had made only stumbling and tentative gains from the sentence, perhaps because they preferred to try and recoup (or grieve) their losses. The attitudes of both fractured and defensive agents toward rehabilitative intervention varied 
according to past identity and experience, and according to the nature of the offence, but all were ambivalent about compliance. None were yet 'swimming with the tide' (Crewe et al. 2016), though some had made hesitant forays. Attending to the conviction's demand for reform (Duff 2001) was not a primary concern; instead, the sentence was to be endured, something that was especially challenging if the tariff was long, if they had not previously been imprisoned, or if a private reckoning with the offence (or past life experience) produced feelings of victimhood. Regardless, most preferred Gartree's 'laid-back' atmosphere to the 'madness' (Thomas) of local prisons or the oppressive 'dead time' (James) of high-security. Periods of meaningless time in environments experienced as unsafe (see Liebling, Hulley, and Crewe 2012) were especially characteristic of dead ends.

Both groups clutched at whatever straws the past could offer, but solace came at the cost of entrenchment and stalemate. Those in dead ends were 'ultimately concerned' with survival in the present (Archer 2000, 2003; cf. Crewe et al. 2016). 'Niches' (Toch 1977) could open up a potentially more productive future, because conditions of safety encouraged reflection on received structures of thought (see Bottoms 2006:284). However, thinking about the future staked the numb comforts of the present against a potentially shameful past, offering only uncertain future rewards.

Even so, most in dead ends recognised that (at the very least) they would have to engage with penal power to progress, though Desmond was an outlier for whom defensiveness was tenable because release was irrelevant. Compliance promised new pains of 'tightness' (see Crewe 2011a:523-24), generating ambivalence or hostility in the defensive agents, and resigned bafflement in the fractured agents, who lacked the confidence to reassure themselves they were playing the system at its own game. Instead, their engagement was a kind of 'dull compulsion' (Carrabine 2005), painful because their yearning to be helped was incompatible with the late-modern penal expectation that they help themselves.

Generally, though, the need to back away from dead ends was anticipated with resignation. However, it was galling to the extent that stigma was felt to be illegitimate, hypocritical, or unjust, and to the extent that change could not be framed in personally meaningful terms. 


\section{Turning points}

\section{'Corrective' agency}

Andy, Davidas, Michael, Owen, Regis, and Sam were the youngest group when sentenced (group mean 21.0 years, sample mean 31.7). Their tariffs were shorter than average (group mean 15.7 years, sample mean 18.1, though ranging from 10 to 23 years) and they had served between a fifth and the whole of the tariff. The transition to adulthood is 'closely linked to role transition, and, probably, to [the development of] a more reflective emotionality' (Bottoms 2006:283), which itself is implicated in agency. All six men linked their past offending to immaturity, or delusions of criminal grandeur: they said they had not been fully adult before prison. Several had pleaded guilty at trial. Only one described his (relatively long) tariff as 'harsh', while the others not only assented to the sentence's terms but seemed to endorse its normative aims:

'I was a bad pillar in society, I brought my community down [...] [So prison is] to make you into a good reformed character.' (Andy)

'It's a punishment. I'm in prison because l've done something wrong, and I'm not accepted outside.' (Owen)

'[P]rison is better than hanging people [...] It stores people, shows them a different path where they might look at themselves. But it's also a punishment, it needs to be, because they took someone's life.' (Davidas)

\section{Attitudes to the offence}

All in this group described adversity in early life: time in state care (Davidas and Andy); being the target of (and witness to) sustained violence in the home (Owen and Davidas), or poverty, parental mental illness and substance abuse (Michael and Regis). ${ }^{9}$ This quote was typical:

'The second I was born, I was dealt a bad hand. It's like my whole life was meant to fail [...] I just always struggled with so much negativity and pain. The country I come from, and the city, it's violent, it's raw... We don't have psychology, therapy. People deal with their problems, not by speaking, but by fighting and drinking.' (Davidas)

These narrations were typical of the 'redemption scripts' described by Maruna (2001), in that the past was described in terms suggesting a good person in a bad world, removal from which had come to seem a necessary if painful corrective. I have labelled their

\footnotetext{
${ }^{9}$ The exception was Sam. He had been in prison for more than half his life, spoke only vaguely about life beforehand, and felt dissociated from his adolescent pre-prison self.
} 
agency using this term. Despite similarities in their 'origin stories', what these men sought to correct depended upon the circumstances of their index offence. For those who linked their offending to gang activities or the drugs trade, the offence itself was conspicuous by its absence. It was as if they understood the sentence to demand the correction of wider criminality, rather than the murder per se, which was not specifically described as shameful. Instead, the offence appeared as the tragic result of misguided commitments:

"I grew up in care, and there was no one to bring me in to tell me, "look, this is what you've got to do." So I looked up to drug dealers and gang-bangers. That was the lifestyle which I was involved in, what I've got to pull myself away from.' (Andy)

"I was proper deluded. I thought, "yeah, I'm going to be this big-time drug dealer, I'm going to have all these women, and a fat mansion, and I'm going to be a rap star." [...] My whole lifestyle and motivation was just money, money, money. But money's not everything.' (Regis)

These men aimed to avoid bad influences in prison and to acquire self-control and autonomy. If they were preoccupied by deeper psychological questions of how and why they had taken life, these were not expressed in the interview.

For all of the others, the offence had been a case of seemingly random violence against a person not presentable as a legitimate criminal foe. It was far more prominent in their narratives, and they presented themselves as people who had taken a life, rather than as people who had unwisely become criminals. The following descriptions are typical:

'If my offence didn't happen, then I wouldn't have wanted to change. [...] I think it was mostly the offence, and my mum and [my girlfriend] talking to me [...] about what it all meant: "You were young and dumb, you've done what you've done before this happened. But this is serious, like. Someone's died because of you."' (Owen)

'You go to OMU meetings [and] it says, "danger to society", or something like this. And it's always like, "I'm not a danger to anybody, what are you on about?" [...] But you have to agree that you are that scumbag, in a way. I kicked the head of a guy who didn't fight back. It was a shitty thing to do. I have to realise that.' (Davidas)

There were distinct 'processes' of desistance for those who saw their index offence as the result of wider criminality, and those who did not (cf. F.-Dufour and Brassard 2014). Even so, all described their actions as wrong, and themselves as seriously committed to change. The commitment came not as an epiphany, but instead a 'faltering, hesitant and 
oscillating' process of reflection. This is typical of offenders considering desistance during the transition to adulthood (Bottoms et al. 2004:383). Even so, they varied strikingly in their styles of reflection and their orientations toward penal power.

\section{Change as private struggle}

All described periods of private reflection. This autonomous reflexivity (Archer 2003) characterised the prison in strikingly moral terms: it was full of 'evil' (Regis) which as (potentially) good men, they had to resist. The sources of evil differed, apparently influenced by prior experiences during the sentence, but salvation lay within the self. Andy, a recent arrival at Gartree following many years hovering around the maximumsecurity 'termini' (Sparks 2002) of high-security prisons, saw the authorities as the foe. Change was a battle against them. Others saw other prisoners as the source of moral threat, with staff hard to trust but not contaminating in the same way.

Confidence in one's potential required time to develop. For Michael (whose desire for change was recent), the 'laddish little banter' of subcultural peers had become tiresome. He wanted 'normal serious conversation', which might help him become 'intellectually smart, articulate, brave, less impulsive.' He thought this would 'give life meaning', but painful (though unspecified) past experience had taught him that self-revelation was dangerous:

'The more you [...] allow yourself to be known by strangers, I believe that's an avenue for them to abuse their position.'

Although, like the others in this sub-group, he desired a different self (see Paternoster and Bushway 2009) his commitment was nascent and vulnerable. 'Reputation' was sticky, and he spent a great deal of time in the cell, avoiding unwanted contact with staff and peers, and hoping that he could tough out the remaining decades of the sentence in this way. He had also recently had been adjudicated against for various infractions; as an early-stage desister he vacillated between 'the push and pull of goals that are incompatible' (Hunter and Farrall 2017:10), in contrast to Andy and Regis, who prided themselves on exemplary recent disciplinary records.

Altering bad behaviour amid the temptations and provocations of prison life was challenging. The 'transvaluation' of emotional commitments (Archer 2000:227; see also Bottoms 2006:264) appeared to build self-control. Regis, Michael, Andy, Owen, and 
Davidas all described learning to 'walk away' from situations, but Owen's was the richest description of the complex emotions involved in dedicating oneself to different commitments:

'Especially on the wing, when [...] someone says something, and you just have to walk off... your head down, you know? It's hard, man. [A] non-criminal person, will think nothing of it, whereas you feel that a bit of pride's been took from you [and] you've been mugged off, [in front of] all those people. It's happened a few times. You just feel like a dickhead... I'll be standing on the cooker [and someone will say], "that's my pot, take [yours] off, get it fucking off there", and you go "I don't want to know, mate" [...] I walk away from it, it's the best thing to do.' (Owen)

The immediate experience was wounded pride, making the experience 'hard'; the lack of immediate emotional outlet was emasculating. But commitment to changed norms framed the experience as meaningful, affixing masculine pride to other commitments. Self-control was also exercised at a distance (Bottoms 2006:280; see also Kennett 2003:134-35) by, for example, withdrawing from certain jobs if the environment was seen to be provocative (several men across the whole sample identified the prison kitchens as risky), even though consequent unemployment could entail further temptation:
I had no work [...] And there's nobody sending me money. And I was struggling - I couldn't even buy toothpaste! [...] I saw people [dealing drugs], I could have easily approached them [and gone back to dealing drugs myself]. And I went through a whole week, I was up all night walking around my cell, constantly disputing [...] banging back and forth, with the pros and cons, yeah? And to tell you the truth, I was THIS close! I was SO close! [But] I thought to myself, "you know what, I'm not gonna do it." That was hard, man! That was hard! [W] hen I couldn't provide for myself, I thought I was reliving my childhood all over again. It was humiliating. I thought, "I can't take this!"' (Regis)

Such stories, told by all the men in this group, described the private re-evaluation of previously unreflected habitual commitments, prompted by emotional crises in prison. Much choice is the result of habitual action, driven by internalised commitments to particular rules of conduct (Bottoms 2006:272-74; cf. Wikström 2006). Most such moral choices 'blend indiscriminately into the flow of practical activity' (Emirbayer and Mische 1998:999), but internal or social reflection frames them as good or bad, leading to 'second-order' (Archer 2000) emotional commitments. Regis (above) weighs the relative value of two commitments - material comforts and rightful behaviour - which his reflexivity reveals to be in conflict. In doing so, he weighs the claims of habitual inertia 
against deliberate dedication to a different course (cf. Archer 2003; Vaughan 2007:39396). This develops narrative themes (agency, the determined quest for change, moral deliberation) which are narrated recursively, framing his identity and sense of the 'real me' (Archer 2000; cf. Maruna 2001:88-108).

\section{Attitudes to rehabilitative intervention}

The extent to which these men embraced the prison's rehabilitative offer varied, as did the styles of compliance they described. All three whose offences had been acts of random violence had willingly engaged with offending behaviour programmes, including long-term therapy in two cases. ${ }^{10}$ They were willing to involve the penal authorities in the change process, and (especially in the context of TCs) this can be seen as a form of social reflexivity, or the reflexive evaluation of behaviour with others (see Bottoms 2006:271; also Emirbayer and Mische 1998:994).

Perhaps as a result, these men seemed more confident in their dealings with penal power. Owen had completed several OBPs while in a high-security prison, with encouragement from his family throughout. He evaluated the rehabilitative promise of courses more flexibly than the 'defensive' agents, though the underlying perception that 'you change yourself' was identical:

'[E]ven though they say, "do this course, it'll change you", courses don't change you, they can guide you, but the only person that can change you is yourself [...] But for those guys who will make an effort to get on with the staff, they know how to encourage you to change your life. How to help you get on with the sentence, get on the courses, that sort of thing.' (Owen)

Many others in the sample also said that staff took more of an interest in prisoners who make the effort to get on with them. Davidas and Sam, meanwhile, had both participated in long-term therapy, which had helped them iron out their offences and mangled early lives:

'Someone sat down with me, and [said], "you know, this is not how you should be answering all these questions [about the offence]? [...] We'd like a bit more. Can you elaborate?" [I said] "I don't know how. That's what happened.' [So they said] "how were you feeling?" [I said] "Well, I were feeling alright." [They said] "Were you sad, were you

\footnotetext{
${ }^{10}$ It was unclear why this was, but they all described their offences in terms suggesting frightening loss of control. The others did not narrate the offence, which hampered comparison, but it is possible that they saw their actions as mistaken but nevertheless controlled - and perhaps less disturbing.
} 
happy?" They're giving you these options. [...] Being taught like that, makes you build up an answer a lot more than the bog-standard answer you gave before.' (Sam)

Andy, Michael and Regis, however, described engaging more reservedly with social life in general and penal power in particular. While (like the defensive agents) they participated in courses instrumentally because it was a condition of progression, they tended to dismiss them as 'common sense' (Andy) or else as 'digging for something that isn't there' (Regis). That is, the course was perceived as legitimate if it matched their own 'sociological' account of their offending, rather than because it helped to correct some deep aspect of the self. Their compliance with courses skittered across the modes described in Bottoms' typology (2002), though they did not approach the sullenness of the defensive agents, and they parroted psychological risk discourse ironically, not with out-and-out disdain.

\section{Wider social resources mobilised for desistance}

Despite courses and other forms of social participation, discussing one's behaviour and cognition with others was rare, except among those with experience of therapy. Instead, accounts of change were mostly dominated by individual selfmonitoring. However, the social life of the prison was the grist of this reflection, and a feature of corrective agency was its development of practices which demonstrated to peers a dedication to 'positive' norms and self-betterment. These can be seen as 'desistance signals' (see Maruna 2012), and they reinforced changed identity at the cost of subcultural credibility:

'I went, "you know it's against prison rules to [smoke] in here?" I put that out there, just to let them know: "look, don't go near him, because he might blow us up". Not that I will - it's just to [let them know].' (Andy)

Just like verbal commitments to the inmate code, 'desistance signals' were performative: they were a way to present the self to others. Prisoners across the entire sample described how a new arrival's boundaries would be tested by other prisoners on his wing. But a reputation for good character, acquired over time, caused such provocations to recede: Regis said that because of his track record on the wing, other prisoners no longer bothered him: 'they know who I am.' This was in marked contrast to Michael, who had not yet developed such signalling techniques, and appeared more isolated as a result. 
The extent to these men embraced 'generative' opportunities in the prison was limited. ${ }^{11}$ Andy, Michael and Regis, who all set their offences in the context of wider criminality, expressed a strong religiosity. This offered them moral fibre and values to live up to:

'To be a Muslim, it means to be peace. It means to be kind to people. To be respectful. To submit yourself to God. To pray, to show appreciation for Him giving you life. And thankfulness. To give charity. To help the poor. To help the needy. To give good advice. And also to educate yourself.' (Regis)

'I used to have a role model that was a drug dealer [...] but now I look up to Jesus, and I just know that I'm forgiven for everything that I've done in my life. Because of his sacrifice for us. And the shedding of his blood. [I]t lets me go of my past, so I can be who I want to be and who I am now.' (Andy)

It may also be that religious faith offered forgiveness, on terms more favourable (and unconditional) than psychological discourse, which in any case they held at a distance. These men were interested in education in principle, but most found what was on offer at Gartree uninspiring, and limited themselves to private reading from the prison library, religious study, and occasional OBPs. Only two of the six corrective agents expressed satisfaction with their prison jobs, and only Regis credited his with a specific role in change:

'I think [workplace] has completely changed the way I interact with staff. I never used to. I was polite, but I only talked to them if I needed a toilet roll or something. And my reports always came back: "Regis has done well but he doesn't engage with staff". I didn't want to. I didn't like it. But [the manager at my workplace] said: "listen, what's the matter with you? When you get out, what are you going to do? You're going to be working, what are you going to say to your manager? 'I feel uncomfortable?' Listen, you're going to have to interact with people outside your social circle." He was right, you know.'

\footnotetext{
${ }^{11}$ It was not clear whether this was a failure of demand or supply.
} 


\section{'Redemptive' agency}

John, Martin and Max were older when sentenced than average (group mean 40.0 years, sample mean 31.7 ) and had received tariffs averaging just under twenty years. All had been imprisoned before, two several times, and all had children. The sentence appeared, again, to have offered time to reflect, but the burden of the past was such that their defences had imploded. All had sought (or been guided to) longterm therapeutic intervention.

Integrating the offence with the self

Redemptive agency pinpointed responsibility for the offence deep within the self, commanding reform (and reparation if possible). They framed their pasts as grave violations of masculine norms such as integrity, self-sufficiency, and protection of family:

'[T]here are some situations where you've been a real arsehole to your family, and they don't want to forgive [...] I struggled with [that] for a long time. But I'd robbed them of their childhood.' (John)

The offence was again significant: all three had killed people known to them. Though they had previously blocked out or ignored the impact of their behaviour on loved ones, private reflection had resulted in intolerable anguish. Defensiveness had, effectively, imploded, and identity had become personally (never mind socially) unintelligible:

'There's a reality sometimes of... [pause] what you've done [...] You just sit down and you think [long pause] "that was wrong. That was... [long pause] Why?" And it's no good just to say, "I don't know." If someone sits in front of you and wants to know why you did this, they're not interested in, "I-don't-knows" or "I'm-sorrys". You've got to come up with some logical explanation. And I think that's where it can get difficult. It can really get difficult.' (John)

John's summoning of an imaginary interlocutor is significant, since it highlights the social negotiation of identity. People have their own sense of themselves, but others read identity from how they perform the expected requirements of social roles (Archer 2000). In stark contrast to defensive agency (which maintained past identity as far as plausible), the redemptive agents had ransacked the past for evidence of its contemptibility:

[I was] pretty trustworthy on the surface, but under a thin veneer of respectability, I was a piece of work. For over a decade I didn't commit an offence, so to speak, [but] that doesn't mean that my life wasn't deeply immoral, in ways you can't be prosecuted for 
[...] I would be very busy with a charity event, but wouldn't have a problem with evading a few grand's worth of taxes, things like that.'

Unlike the younger 'corrective' agents, these men could not foresee family life as a potential source of 'generativity' (Maruna 2001:117-30; Maruna et al. 2004); it was instead an indelible mark of shame. Having attained devastating awareness of the harm they had done others, mindful of death's finality, and beleaguered by feelings that they might 'not deserve forgiveness' (Martin), they sought to redeem the past, not reclaim a future held in abeyance. Far from 'knifing off' the past (Laub and Sampson 2003), integrating it was the only feasible way to 'make good' (Maruna 2001).

\section{Styles of engagement with the penal environment}

All in this group said they had struggled privately with knowledge of their guilt before reaching moments of crisis. A significant factor in all three narratives was the role of prison staff members who had noticed their struggles, and pointed them to a next step; all had ended up in long-term therapeutic interventions, which had taught them a different style of emotional reflection, and an appreciation of other people as autonomous subjects in their own right:
'It took me two years to try and understand what empathy was [...] It's not something that you can just go on a course and tick a few boxes and say, "yeah, yeah, I know what empathy is now." It was a very big thing for me [...] I could then understand what damage I'd caused other people and how they were feeling [...] It was just a massive thing for me.' (John)

TCs have been described as helping prisoners to develop a 'holistic understanding of their life history' (Stevens 2012:541), and can transform traditional prison culture (Genders and Player 1989, 2010). This appeared to relieve the burden of shame and generate a profound re-evaluation of values, as well as a fundamental reconciliation to the fact of their punishment:
'People gripe on about, "yeah, I've lost my freedom, I can't be there for my family". But on the out, without the changes that l've made in jail - knowing them, internalising them - I don't think I would have given a shit. So all the things which are important to me now, I don't think they would ever have been important. I really don't know if I've lost anything that matters.' (Max)

Even so, self-revelation in therapeutic settings involves a 'largely unacknowledged' risk of harm to participants (Genders and Player 2014:450); one man in this group had found 
himself unable to engage in a TC after two attempts, but had accessed one-to-one therapy, obtaining just such a 'holistic understanding' as the others had gained in the GTC. ${ }^{12}$ This suggests that the experience of being helped to come to terms with shame (and not simply the setting in which this takes place) can result in lifers feeling a generalised sense of reciprocal obligation towards the prison. Far more consistently than any other group, these men incorporated other people (including prison personnel) into their narratives of change, as partners rather than narrative foils:

[W] ithout [everybody in the GTC], staff, prisoners, the rest, I wouldn't have been able to do it. It's like an engine, if one little bit's not working right, the whole thing'll break down. It's all got to work together. Else it won't work.' (John)

This included a striking habit, manifest in all three men, of immediately qualifying any criticism of non-therapeutic intervention, even though they felt it offered a less meaningful slant on life, and even though their underlying objection (i.e. 'you rehabilitate yourself') was shared across the entire sample:

'Most of the courses, they're all the same. But it's you. It's you. The courses aren't going to change you. I don't care how good [they are]. That's never going to change you. The only person who is ever going to change you, is you. [pause] But actually, you do get some stuff off them.' (Martin)

The suggestion here is that though nearly all prisoners complied with riskreducing intervention, only those who felt it had answered self-defined needs came to see the interventions as legitimate. For the redemptive agents, two of whom described behaviour earlier in the sentence which was not only disengaged but highly disruptive, this represented a dramatic shift. Similarly, it was striking that (unlike the corrective agents) no one in this group described other social actors - prisoners or staff - as ipso facto a threat to reformed identity. Quite the contrary: they chafed at the listlessness of prisoners who would not 'work' on themselves (as Max put it, 'You've got amends to make, just fucking get on with it'), and all three reflected at length on the perceived laxity of political power in fostering prisons which promoted real change. These

\footnotetext{
${ }^{12}$ It is likely that each of these men was 'high-risk' and therefore a priority for access to 'the right help'. Billy (a 'fractured' agent) and Richard (a 'defensive' agent) both said they would like to access one-to-one therapy, but had been told to expect long waits.
} 
statements hinted that redemptive agents felt secure among the elite of an alternative hierarchy - men brave and tough enough to remake themselves. 


\section{Discussion}

Crewe et al. argue that, following years of disorientation during which some may sink, most lifers 'swim with the tide', recognising prison as 'the only place where life [can] meaningfully be led' (2016:526). The relevance of pre-prison identity fades, and agency becomes 'productive': powers of reflection focus on what of value can be sifted from the experience. The findings presented in this chapter develop that conclusion by describing different styles of private and social reflexivity, pointing to the existence of distinct processes of in-prison desistance (cf. F.-Dufour and Brassard 2014).

The reflexive search for reasons directed some outwards, and others inwards. For corrective agents, answers were framed in terms of maturation and the development of 'character' (Sennett 1998): they were the product of reflection over a long period upon behaviour in given environments, resulting in an evolving handling of different situations. Davidas, Owen and Sam were highly compliant, engaging relatively openly with penal power in projects of self-improvement. They had agreed to bear the stigma of the offence. Accounting for themselves required complex 'causal histories of reasons' (Bottoms 2006:255) and often led them back to traumatic early lives. Therapeutic intervention was particularly helpful here. The same could be said of John, Martin and Max, whose redemptive agency also recognised faulty selfhood, though their commitment to 'make good' was expressed as a quest for self-understanding and, if possible, for forms of forgiveness.

The 'personal criminologies' of Andy, Michael and Regis, by contrast, were sociological, not psychological. The threat of the offence was confronted by making a commitment to change, and by framing the environment as a test of that commitment. Engagement was cautious, reflexivity more inward, and there was a preference for selfsufficiency, where possible. Having been involved in criminal subcultures, these men found compromise with penal power a lengthy process, with uncertain outcomes. A reading of penal power as legitimate (albeit fallible) was only found among those men who had 'partnered' with the prison in their pursuit of change; it appeared far harder for Andy, Michael and Regis to attain.

Despite these distinctions, however, all engaged with rehabilitative interventions, though with different modes of compliance. Only Andy, whose years in high-security had left him committed to vigorous censorious critique of the authorities 
(Mathiesen 1965), explicitly noted the discrepancies between his 'penal avatar' (Crewe 2011a) and the personal relationships which, in his view, determined progression:

'Even though you've done all your courses, or you want to progress, they say... "Oh, we want to get to know you". They have a system called C-NOMIS. [So I say] "C-NOMIS knows me! [...] Why do you want to personally get to know me when you could just look on a computer?" [That's what] I say: "you already know me!"' (Andy)

In general, it appeared difficult to frame personally meaningful change in the terms of risk reduction, except in the case of the GTC and other forms of therapy, which seemed to combine existential with actuarial pertinence (cf. Farrall 2005; Genders and Player 1989; Stevens 2012).

There was no doubt that all of the corrective and redemptive agents saw themselves as changing individuals, but using the methods employed by this study it is impossible to confirm whether they were perceived by the prison as such. Their accounts of adversity in early life and (sometimes nascent) transformations during imprisonment were recognisable in terms of Maruna's (2001) concept of 'applied mythology': their reflexive powers recast past experience in moral terms. Unlike Maruna's desisting sample, though, these men did not seem to consider themselves 'hypermoral', but instead emphasised a sense of constant becoming (see Farrall 2005) in an environment which tested them but could be mastered with practice. 


\section{Chapter 5}

\section{Conclusions}

'Some people will turn up with a big sentence, and they're in denial what they've done. They don't want to talk about it, it's too painful: [adopts small, pitiful voice] "I didn't do it." They did do it, but really, deep down, they want to look at the appeal process. They're not gonna wear it. There is that process. You can't just say to somebody, "look, you need to change, and do this", without that person actually going through that process.' (John)

John concurs with a recent research finding, that the 'sheer heft of the act' (of murder) and 'the severity of the sanction that follows' eventually see to it that prisoners adapt; in the process, all imported differences between them are 'flattened' (Crewe et al. 2016:528). This study suggests modifying that finding: while it may be the act and the sanction which compel adaptation, it is the wider context of both which shapes the kinds of personal change lifers perceive to be necessary, and dedicate themselves to pursuing.

As a whole, the sample divides rather clearly on age when sentenced: those who were younger hoped to understand and leave behind the past, working on a changed self as a kind of expiatory reparation; while those who were older wanted (and often struggled) to understand and come to terms with the past. Another quite clear division was on the nature of the offence. Those who had killed a comparative stranger, especially in the context of wider offending, were less burdened by the act itself. They offered culturally familiar 'sad tales' (Goffman 1963), which framed their offence as regrettable, but not irredeemable. Others' offences had been impossible to narrate in such terms: their victims had been vulnerable, female, family members or loved ones. They had often transgressed masculine norms, and in some cases, had gravely harmed people they now understood they had been supposed to protect. All of this meant they struggled with a far greater burden of shame, needing and seeking more help to come to terms with it.

A further finding of this study was also implicit in John's words above: lifers early in the sentence were especially likely to be stuck in 'dead ends', struggling defensively in private as they grieved what they had lost, without any real temporal incentive to soften their stance. Most understood that to take responsibility required them to create 
plausible explanations (Bottoms 2006). This appeared very difficult for those whose deeds were especially transgressive, grisly or unfathomable. Most men in this study acknowledged the need to give reasons, but those they offered were framed mostly by 'folk theories of mind and behaviour' (Bottoms 2006:255); the 'corrective' and 'redemptive' agents only borrowed the terms of psychological discourse when it suited their own framing of the past, though nearly all had experience of psychological interventions. By contrast, a small minority of 'fractured reflexives' offered only incoherent explanations for what they had done, appearing to believe that they had had no freedom to do otherwise. This differed from the defensive agents' claim that (for example) provocation rendered their actions justifiable.

Besides expanding what is known about styles of adaptation, a desistance lens also clarifies some tentative conclusions about the kinds of institutional conditions which support change. The desire to progress in the sentence meant finding ways to demonstrate change, and appeared so common that only those early in the sentence (or late in life) forswore it entirely. Moments of crisis were prominent in accounts of change, and were often framed as calling for a new style of reflexivity and selfunderstanding. If the prison was able to offer support at these moments in a way they experienced as meaningful, they tended to express a lasting sense of reciprocal obligation. Arguably, penal authorities should regard this as a potential asset in which to invest. Nevertheless, the extent to which prisoners were able to access meaningful support depended on their self-presentational skill and actuarial classification, however intense the self-defined need they experienced. Those caught in 'dead ends' might have experienced such need without feeling able to seek, or being able to obtain, the help they wanted. One feature of many men's 'corrective' and 'redemptive' agency was the deliberate cultivation of relationships with offender managers and other key staff. As Max put it:

'you have to do your utmost to make yourself into more than a name on a folder [...] $A$ lot of guys don't get that, they fight all the way through, going [speaking through gritted teeth] "I will not be broken" and all this bullshit. But you can't get anywhere like that.'

Much of the personal change they experienced seemed rather private, and even perhaps opaque to the authorities; further ethnographic research in this area might be fruitful. It was striking how few of the lifers in the sample (two men) were involved in 
officially-sanctioned roles which could be described as 'generative', and one of these (Joe) explicitly denied this was associated with change. Despite this, everyday life on the wings and in the workshops offered countless situations which individuals narrated as if they were morally and ethically significant. The purpose of telling these stories was to reflect on the quality of one's decision-making, not always to boast of having reached the right decision. In short, nearly all of what were framed as significant moral turning points took place elsewhere than in the OBP classrooms, raising the possibility of currents of personal change within prisons which are as ubiquitous and yet as hard to observe as the informal economy. Lifers in this sample who perceived themselves as changing people found ways to signal changed identity to one another, and as they did so, (re)built reputation and 'character' (Sennett 1998). They often reflected on and reevaluated emotional commitments, and dedicated themselves to new forms of redefined masculine esteem.

Undoubtedly, there are limitations to the analysis. The sample is small and the study cross-sectional, and it was not feasible to triangulate more than the outline details of index offences. It is unlikely that all eighteen men were lying, but equally unlikely that all who knew them (in prison and outside) would unreservedly endorse their selfdescriptions. Absent from the analysis is data to facilitate comparisons between these men's risk status, self-concept and perception among staff. Their construction as 'transformative risk subjects' (Hannah-Moffat 2005; Robinson 2008) was therefore invisible to me, just as it seemed to be to some of them. Even so, it should be a matter of concern that many defined and pursued projects of personal change with only limited reference to the interventions the prison offered them, and that the non-therapeutic interventions were accorded such limited prominence in their accounts of change. This underlines the importance of resolving debate (e.g. McNeill 2012; Polaschek 2016) as to whether the RNR and desistance paradigms of rehabilitation can be reconciled. 


\section{References}

Andrews, Donald A. and James Bonta. 2015. The Psychology of Criminal Conduct. 5th ed. London; New York, NY: Routledge.

Archer, Margaret S. 2000. Being Human: The Problem of Agency. Cambridge: Cambridge University Press. Retrieved (http://ebooks.cambridge.org/ref/id/CBO9780511488733).

Archer, Margaret S. 2003. Structure, Agency and the Internal Conversation. Cambridge: Cambridge University Press. Retrieved (http://ebooks.cambridge.org/ref/id/СBO9781139087315).

Archer, Margaret S. 2012. The Reflexive Imperative in Late Modernity. Cambridge: Cambridge University Press. Retrieved (http://ebooks.cambridge.org/ref/id/CBO9781139108058).

Barnes, Barry. 2000. Understanding Agency: Social Theory and Responsible Action. London: Sage.

Bottoms, Anthony E. 2002. "Morality, Crime, Compliance and Public Policy." Pp. 20-51 in Ideology, Crime and Criminal Justice: A Symposium in Honour of Sir Leon Radzinowicz, edited by A. E. Bottoms and M. Tonry. Cullompton: Willan.

Bottoms, Anthony E. 2006. "Desistance, Social Bonds, and Human Agency: A Theoretical Exploration." Pp. 243-90 in The Explanation of Crime, edited by P.-O. H. Wikström and R. J. Sampson. Cambridge: Cambridge University Press. Retrieved (http://ebooks.cambridge.org/ref/id/CBO9780511489341A017).

Bottoms, Anthony E., Joanna Shapland, Andrew Costello, Deborah Holmes, and Grant Muir. 2004. "Towards Desistance: Theoretical Underpinnings for an Empirical Study." The Howard Journal of Criminal Justice 43(4):368-89. Retrieved (http://doi.wiley.com/10.1111/j.1468-2311.2004.00336.x).

British Society of Criminology. 2015. "Statement of Ethics." Retrieved August 10, 2017 (http://www.britsoccrim.org/documents/BSCEthics2015.pdf).

Broom, Alex, Kelly Hand, and Philip Tovey. 2009. "The Role of Gender, Environment and Individual Biography in Shaping Qualitative Interview Data." International Journal of Social Research Methodology 12(1):51-65. Retrieved (http://www.tandfonline.com/doi/abs/10.1080/13645570701606028).

Brownlee, Kimberley. 2011. "The Offender's Part in the Dialogue." Pp. 54-67 in Crime, Punishment, and Responsibility: The jurisprudence of Antony Duff, edited by R. Cruft, M. H. Kramer, and M. R. Reiff. Oxford: Oxford University Press.

Burnett, Ros. 2006. "The Kindness of Prisoners: Strengths-Based Resettlement in Theory and in Action." Criminology and Criminal Justice 6(1):83-106. Retrieved (http://crj.sagepub.com/cgi/doi/10.1177/1748895806060668).

Burnett, Ros and Shadd Maruna. 2004. "So 'Prison Works', Does It? The Criminal Careers of 130 Men Released from Prison under Home Secretary, Michael Howard." The Howard Journal of Criminal Justice 43(4):390-404. Retrieved (http://doi.wiley.com/10.1111/j.14682311.2004.00337.x).

Burnett, Ros and Fergus McNeill. 2005. "The Place of the Officer-Offender Relationship in Assisting Offenders to Desist from Crime." Probation Journal 52(3):221-42. Retrieved (http://journals.sagepub.com/doi/10.1177/0264550505055112).

Carrabine, Eamonn. 2005. "Prison Riots, Social Order and the Problem of Legitimacy." British 
Journal of Criminology 45(6):896-913. Retrieved (https://academic.oup.com/bjc/articlelookup/doi/10.1093/bjc/azi052).

Cavadino, Michael and James Dignan. 2006. "Penal Policy and Political Economy." Criminology and Criminal Justice 6(4):435-56. Retrieved

(http://crj.sagepub.com/cgi/doi/10.1177/1748895806068581).

Clemmer, Donald. 1958. The Prison Community. New York, NY: Holt, Rinehart and Winston.

Cohen, Stanley and Laurie Taylor. 1972. Psychological Survival: The Experience of Long-Term Imprisonment. Harmondsworth: Penguin.

Creswell, John W. 2013. Qualitative Inquiry \& Research Design: Choosing among Five Approaches. 3rd ed. Thousand Oaks, CA; London: Sage.

Crewe, Ben. 2006. "Power, Adaptation and Resistance in a Late-Modern Men's Prison." British Journal of Criminology 47(2):256-75. Retrieved (https://academic.oup.com/bjc/articlelookup/doi/10.1093/bjc/azl044).

Crewe, Ben. 2009. The Prisoner Society: Power, Adaptation and Social Life in an English Prison. Oxford: Oxford University Press. Retrieved (http://www.oxfordscholarship.com/view/10.1093/acprof:oso/9780199577965.001.0001/ acprof-9780199577965).

Crewe, Ben. 2011a. "Depth, Weight, Tightness: Revisiting the Pains of Imprisonment." Punishment \& Society 13(5):509-29. Retrieved (http://journals.sagepub.com/doi/10.1177/1462474511422172).

Crewe, Ben. 2011b. "Soft Power in Prison: Implications for Staff-Prisoner Relationships, Liberty and Legitimacy." European Journal of Criminology 8(6):455-68. Retrieved (http://journals.sagepub.com/doi/10.1177/1477370811413805).

Crewe, Ben, Susie Hulley, and Serena Wright. 2016. "Swimming with the Tide: Adapting to LongTerm Imprisonment." Justice Quarterly 34(3):517-41. Retrieved (https://www.tandfonline.com/doi/full/10.1080/07418825.2016.1190394).

Crewe, Ben, Alison Liebling, and Susie Hulley. 2014. "Heavy-Light, Absent-Present: Rethinking the 'weight' of Imprisonment." The British Journal of Sociology 65(3):387-410. Retrieved (http://doi.wiley.com/10.1111/1468-4446.12084).

Crewe, Ben, Alison Liebling, Nicola Padfield, and Graham Virgo. 2014. "Joint Enterprise: The Implications of an Unfair and Unclear Law." Criminal Law Review 4:249-66.

Crewe, Ben, Jason Warr, Peter Bennett, and Alan Smith. 2014. "The Emotional Geography of Prison Life." Theoretical Criminology 18(1):56-74. Retrieved (http://journals.sagepub.com/doi/10.1177/1362480613497778).

Cunha, Manuela. 2014. "The Ethnography of Prisons and Penal Confinement." Annual Review of Anthropology 43(1):217-33. Retrieved (http://www.annualreviews.org/doi/10.1146/annurev-anthro-102313-030349).

Digard, Léon. 2010. "When Legitimacy Is Denied: Offender Perceptions of the Prison Recall System." Probation Journal 57(1):43-61. Retrieved (http://journals.sagepub.com/doi/10.1177/0264550509354672).

Duff, R.Antony. 2001. Punishment, Communication and Community. New York, NY; Oxford: Oxford University Press. 
Ellis, Sophie and Erica Bowen. 2017. "Factors Associated with Desistance from Violence in Prison: An Exploratory Study." Psychology, Crime \& Law 23(6):601-19. Retrieved (https://www.tandfonline.com/doi/full/10.1080/1068316X.2017.1290090).

Emirbayer, Mustafa and Ann Mische. 1998. "What Is Agency?" American Journal of Sociology 103(4):962-1023. Retrieved (http://www.journals.uchicago.edu/doi/10.1086/231294).

F.-Dufour, Isabelle and Renée Brassard. 2014. "The Convert, the Remorseful and the Rescued: Three Different Processes of Desistance from Crime." Australian \& New Zealand Journal of Criminology 47(3):313-35. Retrieved (http://anj.sagepub.com/lookup/doi/10.1177/0004865814523972).

Farrall, Stephen. 2005. "On the Existential Aspects of Desistance from Crime." Symbolic Interaction 28(3):367-86. Retrieved (http://doi.wiley.com/10.1525/si.2005.28.3.367).

Farrington, David P. 1986. "Age and Crime" edited by M. Tonry and N. Morris. Crime and Justice 7:189-250. Retrieved (http://www.journals.uchicago.edu/doi/10.1086/449114).

Feeley, Malcolm M. and Jonathan Simon. 1992. "The New Penology: Notes on the Emerging Strategy of Corrections and Its Implications." Criminology 30(4):449-74. Retrieved (http://doi.wiley.com/10.1111/j.1745-9125.1992.tb01112.x).

Fox, Kathryn J. 2014. "Restoring the Social: Offender Reintegration in a Risky World." International Journal of Comparative and Applied Criminal Justice 38(3):235-56. Retrieved (http://www.tandfonline.com/doi/abs/10.1080/01924036.2013.848221).

Frankl, Viktor E. 2008. Man's Search for Meaning. Kindle ed. London: Rider.

Genders, Elaine and Elaine Player. 1989. Grendon: A Study of a Therapeutic Community within the Prison System. Oxford: University of Oxford Centre for Criminological Research.

Genders, Elaine and Elaine Player. 2010. "Therapy in Prison: Revisiting Grendon 20 Years On." The Howard Journal of Criminal Justice 49(5):431-50. Retrieved (http://doi.wiley.com/10.1111/j.1468-2311.2010.00635.x).

Genders, Elaine and Elaine Player. 2014. "Rehabilitation, Risk Management and Prisoners' Rights." Criminology and Criminal Justice 14(4):434-57. Retrieved (http://crj.sagepub.com/cgi/content/abstract/14/4/434N2 -).

Giordano, Peggy C., Stephen A. Cernkovich, and Jennifer L. Rudolph. 2002. "Gender, Crime, and Desistance: Toward a Theory of Cognitive Transformation." American Journal of Sociology 107(4):990-1064. Retrieved (http://www.journals.uchicago.edu/doi/10.1086/343191).

Goffman, Erving. 1961. Asylums. Harmondsworth: Penguin.

Goffman, Erving. 1963. Stigma: Notes on the Management of Spoiled Identity. Englewood Cliffs, NJ: Prentice-Hall.

Grounds, Adrian T. 2005. "Understanding the Effects of Wrongful Imprisonment." Crime and Justice 32(2005):1-58. Retrieved (http://www.jstor.org/stable/3488358).

Haney, Craig. 2006. Reforming Punishment: Psychological Limits to the Pains of Imprisonment. Washington, DC: American Psychological Association.

Hannah-Moffat, Kelly. 2005. "Criminogenic Needs and the Transformative Risk Subject: Hybridizations of Risk/need in Penality." Punishment \& Society 7(1):29-51. Retrieved (http://pun.sagepub.com/cgi/doi/10.1177/1462474505048132). 
Hannah-Moffat, Kelly. 2013. "Actuarial Sentencing: An 'Unsettled' Proposition." Justice Quarterly 30(2):270-96. Retrieved

(http://www.tandfonline.com/doi/abs/10.1080/07418825.2012.682603).

Hannah-Moffat, Kelly. 2014. "Moving Targets: Reputational Risk, Rights and Accountability in Punishment." 8th Annual SCCJR Lecture. Retrieved July 8, 2017

(http://www.sccjr.ac.uk/publications/moving-targets-reputational-risk-rights-andaccountability-in-punishment/).

HMIP. 2014. "Report on an Unannounced Inspection of HMP Gartree." Retrieved June 30, 2017 (https://www.justiceinspectorates.gov.uk/hmiprisons/wpcontent/uploads/sites/4/2014/07/Gartree-2014-web-amended1.pdf).

Hulley, Joanne L. 2016. "'While This Does Not in Any Way Excuse My Conduct...': The Role of Treatment and Neutralizations in Desistance From Sexual Offending." International Journal of Offender Therapy and Comparative Criminology 60(15):1776-90. Retrieved (http://ijo.sagepub.com/cgi/doi/10.1177/0306624X16668177).

Hunter, Ben and Stephen Farrall. 2017. "Emotions, Future Selves and the Process of Desistance." The British Journal of Criminology 1-18. Retrieved (https://academic.oup.com/bjc/articlelookup/doi/10.1093/bjc/azx017).

IMB. 2017. "Annual Report of the Independent Monitoring Board at HMP Gartree, 2015/16." 122. Retrieved June 30, 2017 (http://www.imb.org.uk/wpcontent/uploads/2017/06/Gartree-2015-16-1.pdf).

Irwin, John. 2009. Lifers: Seeking Redemption in Prison. New York, NY: Routledge.

Irwin, John and Donald R. Cressey. 1962. "Thieves, Convicts and the Inmate Culture." Social Problems 10(2):142-55. Retrieved (https://academic.oup.com/socpro/articlelookup/doi/10.2307/799047).

Jacobs, James B. 1977. Stateville: The Penitentiary in Mass Society. Chicago, IL: University of Chicago Press.

Kazemian, Lila and Jeremy Travis. 2015. "Imperative for Inclusion of Long Termers and Lifers in Research and Policy." Criminology \& Public Policy 14(2):355-95. Retrieved (http://doi.wiley.com/10.1111/1745-9133.12126).

Kennett, Jeanette. 2003. Agency and Responsibility: A Common-Sense Moral Psychology. Oxford: Oxford University Press. Retrieved (http://www.oxfordscholarship.com/view/10.1093/acprof:oso/9780199266302.001.0001/ acprof-9780199266302).

Kruttschnitt, Candace, Rosemary Gartner, and Amy Miller. 2000. "Doing Her Own Time? Women's Responses to Prison in the Context of the Old and the New Penology." Criminology 38(3):681-718. Retrieved (http://doi.wiley.com/10.1111/j.17459125.2000.tb00903.x).

Laub, John H., Daniel S. Nagin, and Robert J. Sampson. 1998. "Trajectories of Change in Criminal Offending: Good Marriages and the Desistance Process." American Sociological Review 63(2):225. Retrieved (http://www.jstor.org/stable/2657324).

Laub, John H. and Robert J. Sampson. 2003. Shared Beginnings, Divergent Lives: Delinquent Boys to Age 70. Cambridge, MA; London: Harvard University Press.

Laws, Ben and Ben Crewe. 2016. "Emotion Regulation among Male Prisoners." Theoretical 
Criminology 20(4):529-47. Retrieved

(http://tcr.sagepub.com/cgi/doi/10.1177/1362480615622532).

Layder, Derek. 1998. Sociological Practice: Linking Theory and Research. London: Sage.

Layder, Derek. 2013. Doing Excellent Small-Scale Research. London: Sage.

LeBel, Thomas P., Ros Burnett, Shadd Maruna, and Shawn D. Bushway. 2008. "The 'Chicken and Egg' of Subjective and Social Factors in Desistance from Crime." European Journal of Criminology 5(2):131-59. Retrieved (http://euc.sagepub.com/cgi/doi/10.1177/1477370807087640).

Lemert, Edwin. 1951. Social Pathology: A Systematic Approach to the Study of Sociopathic Behavior. New York, NY: McGraw-Hill.

Liebling, Alison. 2001. "Whose Side Are We on? Theory, Practice and Allegiances in Prisons Research." British Journal of Criminology 41(3):472-84. Retrieved (https://academic.oup.com/bjc/article-lookup/doi/10.1093/bjc/41.3.472).

Liebling, Alison. 2011. "The Cost to Prison Legitimacy of Cuts." Prison Service Journal (198):3-11. Retrieved (https://www.crimeandjustice.org.uk/publications/psj/prison-service-journal198).

Liebling, Alison. 2017. "The Meaning of Ending Life in Prison." Journal of Correctional Health Care 23(1):20-31. Retrieved (http://journals.sagepub.com/doi/10.1177/1078345816685070).

Liebling, Alison and Helen Arnold. 2012. "Social Relationships between Prisoners in a Maximum Security Prison: Violence, Faith, and the Declining Nature of Trust." Journal of Criminal Justice 40(5):413-24. Retrieved (http://linkinghub.elsevier.com/retrieve/pii/S0047235212000803).

Liebling, Alison, Susie Hulley, and Ben Crewe. 2012. "Conceptualising and Measuring the Quality of Prison Life." Pp. 358-72 in The Sage Handbook of Criminological Research Methods, edited by D. Gadd, S. Karstedt, and S. F. Messner. London: Sage.

Liebling, Alison and Shadd Maruna. 2005. "Introduction: The Effects of Imprisonment Revisited." Pp. 1-29 in The Effects of Imprisonment, edited by A. Liebling and S. Maruna. Cullompton: Willan.

Marshall, Martin N. 1996. "Sampling for Qualitative Research." Family Practice 13(6):522-26. Retrieved (https://academic.oup.com/fampra/articlelookup/doi/10.1093/fampra/13.6.522).

Maruna, Shadd. 2001. Making Good: How Ex-Convicts Reform and Rebuild Their Lives. Washington, DC: American Psychological Association.

Maruna, Shadd. 2012. "Elements of Successful Desistance Signaling." Criminology \& Public Policy 11(1):73-86. Retrieved (http://doi.wiley.com/10.1111/j.1745-9133.2012.00789.x).

Maruna, Shadd and Heith Copes. 2005. "What Have We Learned from Five Decades of Neutralization Research?" Crime and Justice 32:221-320. Retrieved (http://www.jstor.org/stable/3488361).

Maruna, Shadd and Stephen Farrall. 2004. "Desistance from Crime: A Theoretical Reformulation." Pp. 171-94 in Soziologie der Kriminalität (Kölner Zeitschrift für Soziologie und Sozialpsychologie Sonderheft), vol. 43, edited by D. Oberwittler and S. Karstedt. Wiesbaden: Verlag für Sozialwissenschaften. 
Maruna, Shadd, Thomas P. LeBel, and Charles S. Lanier. 2004. "Generativity behind Bars: Some 'redemptive Truth' about Prison Society." Pp. 131-51 in The generative society: Caring for future generations., edited by E. de St. Aubin, D. P. McAdams, and T. Kim. Washington: American Psychological Association. Retrieved (http://content.apa.org/books/10622-009).

Mathiesen, Thomas. 1965. The Defences of the Weak: A Sociological Study of a Norwegian Correctional Institution. London: Tavistock.

McNeill, Fergus. 2006. "A Desistance Paradigm for Offender Management." Criminology and Criminal Justice 6(1):39-62. Retrieved (http://crj.sagepub.com/cgi/doi/10.1177/1748895806060666).

McNeill, Fergus. 2012. "Counterblast: A Copernican Correction for Community Sentences?" The Howard Journal of Criminal Justice 51(1):94-99. Retrieved (http://doi.wiley.com/10.1111/j.1468-2311.2011.00699.x).

McNeill, Fergus. 2016. "The Fuel in the Tank or the Hole in the Boat? Can Sanctions Support Desistance?" Pp. 265-81 in Global perspectives on desistance: reviewing what we know and looking to the future, edited by J. Shapland, S. Farrall, and A. Bottoms. Abingdon: Routledge.

McNeill, Fergus, Stephen Farrall, Claire Lightowler, and Shadd Maruna. 2012. "How and Why People Stop Offending: Discovering Desistance." IRISS Insights (April):1-13. Retrieved April 12, 2017 (http://eprints.gla.ac.uk/79860/).

McNeill, Fergus and Marguerite Schinkel. 2016. "Prisons and Desistance." Pp. 607-21 in Handbook on prisons, edited by Y. Jewkes, B. Crewe, and J. Bennett. Abingdon; New York, NY: Routledge.

McNeill, Fergus and Beth Weaver. 2010. "Changing Lives? Desistance Research and Offender Management." (2010). Retrieved November 12, 2016 (http://www.sccjr.ac.uk/wpcontent/uploads/2012/11/Report_2010_03_-_Changing_Lives.pdf).

Medlicott, Diana. 2004. "Condemned to Artifice and Prevent from Being a Pirate: How Prisoners Convicted of Terrible Crimes Recognize Themselves in Discourse." Pp. 78-92 in This thing of darkness: Perspectives on evil and human wickedness, edited by R. P. Hamilton and M. S. Breen. Amsterdam: Rodopi.

Ministry of Justice. 2017. "Proven Re-Offending Statistics Quarterly Bulletin, July 2014 to June 2015." Retrieved August 2, 2017 (https://www.gov.uk/government/uploads/system/uploads/attachment_data/file/611174 /proven-reoffending-2015-q2.pdf).

Newton, Carolyn. 1994. "Gender Theory and Prison Sociology: Using Theories of Masculinities to Interpret the Sociology of Prisons for Men." The Howard Journal of Criminal Justice 33(3):193-202. Retrieved (http://doi.wiley.com/10.1111/j.1468-2311.1994.tb00806.x).

O'Donnell, Ian. 2014. Prisoners, Solitude, and Time. Oxford: Oxford University Press. Retrieved (http://www.oxfordscholarship.com/view/10.1093/acprof:oso/9780199684489.001.0001/ acprof-9780199684489).

Padfield, Nicola. 2005. "Back Door Sentencing': Is Recall to Prison a Penal Process?" The Cambridge Law Journal 64(2):276-79. Retrieved (http://www.journals.cambridge.org/abstract_S000819730524686X).

Padfield, Nicola. 2016. "Reflections on Sentencing in England and Wales." Pp. 231-58 in The Psychology of Crime, Policing and the Courts, edited by A. Kapardis and D. P. Farrington. 
London: Routledge.

Paternoster, Raymond and Shawn D. Bushway. 2009. "Desistance and The 'feared Self': Toward an Identity Theory of Criminal Desistance." The Journal of Criminal Law and Criminology 99(4):1103-56. Retrieved

(http://scholarlycommons.law.northwestern.edu/jclc/vol99/iss4/5).

Patton, Michael Q. 2015. Qualitative Research and Evaluation Methods. 4th ed. Los Angeles, CA: Sage.

Polaschek, Devon L. L. 2016. "Desistance and Dynamic Risk Factors Belong Together." Psychology, Crime \& Law 22(1-2):171-89. Retrieved (http://www.tandfonline.com/doi/full/10.1080/1068316X.2015.1114114).

Presser, Lois and Sveinung Sandberg. 2015. "Introduction: What Is the Story?" Pp. 1-20 in Narrative Criminology: Understanding Stories of Crime, edited by L. Presser and S. Sandberg. New York, NY; London: New York University Press.

Prison Reform Trust. 2016. "Bromley Briefings Prison Factfile: Autumn 2016." Retrieved July 31, 2017 (http://www.prisonreformtrust.org.uk/Portals/0/Documents/Bromley Briefings/Autumn 2016 Factfile.pdf).

Robinson, Gwen. 2008. "Late-Modern Rehabilitation: The Evolution of a Penal Strategy." Punishment \& Society 10(4):429-45. Retrieved (http://pun.sagepub.com/cgi/doi/10.1177/1462474508095319).

Sampson, Robert J. and John H. Laub. 1993. Crime in the Making: Pathways and Turning Points through Life. Cambridge, MA; London: Harvard University Press.

Sandberg, Sveinung. 2010. "What Can 'Lies' Tell Us about Life? Notes towards a Framework of Narrative Criminology." Journal of Criminal Justice Education 21(4):447-65. Retrieved (http://www.tandfonline.com/doi/abs/10.1080/10511253.2010.516564).

Sandberg, Sveinung, Sébastien Tutenges, and Heith Copes. 2015. "Stories of Violence: A Narrative Criminological Study of Ambiguity." British Journal of Criminology 55(6):1168-86. Retrieved (https://academic.oup.com/bjc/article-lookup/doi/10.1093/bjc/azv032).

Schinkel, Marguerite. 2014. Being Imprisoned: Punishment, Adaptation and Desistance. Basingstoke: Palgrave Macmillan.

Schinkel, Marguerite. 2015. "Hook for Change or Shaky Peg? Imprisonment, Narratives and Desistance." European Journal of Probation 7(1):5-20. Retrieved (http://journals.sagepub.com/doi/10.1177/2066220315575204).

Sennett, Richard. 1998. The Corrosion of Character: The Personal Consequences of Work in the New Capitalism. New York, NY: W. W. Norton.

Shapland, Joanna and Anthony E. Bottoms. 2011. "Reflections on Social Values, Offending and Desistance among Young Adult Recidivists." Punishment \& Society 13(3):256-82. Retrieved (http://pun.sagepub.com/cgi/doi/10.1177/1462474511404334).

Shover, Neal. 1985. Aging Criminals. Beverly Hills, CA; London: Sage.

Sim, Joe. 1994. "Tougher than the Rest? Men in Prison." Pp. 100-117 in Just Boys Doing Business? Men, Masculinities and Crime, edited by T. Newburn and E. A. Stanko. London: Routledge.

Skills Funding Agency. 2015. "Funding Rates and Formula 2015 to 2016 (Version 2)." Retrieved 
July 12,2017

(https://www.gov.uk/government/uploads/system/uploads/attachment_data/file/414784 /Funding_rates_and_formula_2015_to_2016_v2.pdf).

Smith, Kevin B. 2002. "Typologies, Taxonomies, and the Benefits of Policy Classification." Policy Studies Journal 30(3):379-95. Retrieved (http://doi.wiley.com/10.1111/j.15410072.2002.tb02153.x).

Sparks, Richard, Anthony E. Bottoms, and Will Hay. 1996. Prisons and the Problem of Order. Oxford: Oxford University Press. Retrieved (http://www.oxfordscholarship.com/view/10.1093/acprof:oso/9780198258186.001.0001/ acprof-9780198258186).

Sparks, Richard F. 1994. "Can Prisons Be Legitimate? Penal Politics, Privatization, and the Timeliness of an Old Idea." The British Journal of Criminology 34(5):14-28. Retrieved (http://heinonline.org/HOL/Page?handle=hein.journals/bjcrim34\&id=\&page=\&collection=j ournals\&id=560).

Sparks, Richard F. 2002. "Out of the 'Digger': The Warrior's Honour and the Guilty Observer." Ethnography 3(4):556-81. Retrieved (http://eth.sagepub.com/cgi/doi/10.1177/1466138102003004020).

Sparks, Richard F. and Anthony E. Bottoms. 1995. "Legitimacy and Order in Prisons." British Journal of Sociology 46(1):45-62. Retrieved (http://www.jstor.org/stable/591622).

Sparks, Richard F. and Anthony E. Bottoms. 2008. "Legitimacy and Imprisonment Revisited: Some Notes on the Problem of Order Ten Years after." Pp. 91-104 in The Culture of Prison Violence, edited by J. M. Byrne, F. S. Taxman, and D. C. Hummer. Boston, MA: Allyn \& Bacon.

Stevens, Alisa. 2012. "I Am the Person Now I Was Always Meant to Be': Identity Reconstruction and Narrative Reframing in Therapeutic Community Prisons." Criminology and Criminal Justice 12(5):527-47. Retrieved (https://doi.org/10.1177/1748895811432958).

Sykes, Gresham M. 1958. The Society of Captives: A Study of a Maximum Security Prison. Princeton, NJ: Princeton University Press.

Sykes, Gresham M. and Sheldon L. Messinger. 1960. "The Inmate Social System." Pp. 5-19 in Theoretical studies in social organisation of the prison, edited by R. A. Cloward et al. New York, NY: Social Science Research Council.

Toch, Hans. 1977. Living in Prison: The Ecology of Survival. New York, NY: Free Press.

Toch, Hans. 2008. "Cumulative Default: The Cost of Disruptive Prison Careers." Criminal Justice and Behavior 35(8):943-55. Retrieved (http://journals.sagepub.com/doi/10.1177/0093854808318594).

Ugelvik, Thomas. 2014. Power and Resistance in Prison: Doing Time, Doing Freedom. Basingstoke; New York, NY: Palgrave.

Ugelvik, Thomas. 2015. "The Rapist and the Proper Criminal: The Exclusion of Immoral Others as Narrative Work on the Self." Pp. 1-26 in Narrative Criminology: Understanding Stories of Crime, edited by L. Presser and S. Sandberg. New York, NY; London: New York University Press.

Vaughan, Barry. 2007. "The Internal Narrative of Desistance." British Journal of Criminology 47(3):390-404. Retrieved (https://academic.oup.com/bjc/article- 
lookup/doi/10.1093/bjc/azl083).

Waldram, James B. 2007. "Everybody Has a Story: Listening to Imprisoned Sexual Offenders."

Qualitative Health Research 17(7):963-70. Retrieved

(http://journals.sagepub.com/doi/10.1177/1049732307306014).

Warr, Mark. 2016. “Crime and Regret." Emotion Review 8(3):231-39. Retrieved

(http://journals.sagepub.com/doi/10.1177/1754073915586818).

Weaver, Beth. 2014. "Control or Change? Developing Dialogues between Desistance Research and Public Protection Practices." Probation Journal 61(1):8-26. Retrieved (http://prb.sagepub.com/content/61/1/8.abstract).

Wikström, Per-Olof H. 2006. "Individuals, Settings, and Acts of Crime: Situational Mechanisms and the Explanation of Crime." Pp. 61-107 in The Explanation of Crime: Context, mechanisms and development, edited by P.-O. H. Wikström and R. J. Sampson. Cambridge: Cambridge University Press.

Wikström, Per-Olof H. 2014. Analytical Sociology. 1st ed. edited by G. Manzo. Chichester: John Wiley \& Sons, Ltd. Retrieved (http://doi.wiley.com/10.1002/9781118762707).

Wikström, Per-Olof H., Dietrich Oberwittler, Kyle Treiber, and Beth Hardie. 2012. Breaking Rules : The Social and Situational Dynamics of Young People's Urban Crime. Oxford: Oxford University Press.

Williams, Christine L. and E.Joel Heikes. 1993. "The Importance of Researchers' Gender in the inDepth Interview: Evidence from Two Case Studies of Male Nurses." Gender \& Society 7(2):280-91. Retrieved (http://journals.sagepub.com/doi/10.1177/089124393007002008).

World Bank. 2016. "Life Expectancy at Birth, Male (Years)." World Bank DataBank. Retrieved April 5, 2017 (http://data.worldbank.org/indicator/SP.DYN.LE00.MA.IN?locations=GB).

Wright, Serena, Ben Crewe, and Susie Hulley. 2017. "Suppression, Denial, Sublimation: Defending against the Initial Pains of Very Long Life Sentences." Theoretical Criminology 21(2):225-46. Retrieved (http://journals.sagepub.com/doi/10.1177/1362480616643581). 


\section{Appendices}

Appendix 1: Sentence and demographic information about prisoners in the sample Table 3: Summary information about the sample ( $n=18)$, sorted in descending $P Q$ order.

\begin{tabular}{|c|c|c|c|c|c|c|c|c|c|c|c|c|c|}
\hline Pseudonym & $\begin{array}{c}\text { Self- } \\
\text { reported } \\
\text { ethnicity }\end{array}$ & Religion & $\begin{array}{c}\text { Highest } \\
\text { education } \\
\text { completed? }\end{array}$ & Marital status & $\begin{array}{c}\text { Children } \\
\text { before } \\
\text { prison? }\end{array}$ & Age & $\begin{array}{l}\text { Age when } \\
\text { sentenced }\end{array}$ & $\begin{array}{l}\text { Previous } \\
\text { sentences }\end{array}$ & $\begin{array}{c}\text { Age at } \\
\text { earliest } \\
\text { prior } \\
\text { conviction }\end{array}$ & $\begin{array}{c}\text { Tariff } \\
\text { served }^{13}\end{array}$ & $P Q$ & $\begin{array}{l}\text { Considers } \\
\text { himself } \\
\text { guilty as } \\
\text { charged? }\end{array}$ & $\begin{array}{c}\text { How } \\
\text { selected? }^{14}\end{array}$ \\
\hline Joe & $\begin{array}{l}\text { White } \\
\text { (British) }\end{array}$ & - & $\begin{array}{l}\text { Masters } \\
\text { degree }\end{array}$ & $\begin{array}{l}\text { Single, never } \\
\text { married }\end{array}$ & - & $30-39$ & $20-29$ & - & - & $7 \%$ & 25 & $\checkmark$ & $\mathrm{R}$ \\
\hline Pete & $\begin{array}{l}\text { White } \\
\text { (British) }\end{array}$ & - & GCSES & Divorced & $\begin{array}{l}\text { Shared } \\
\text { custody }\end{array}$ & $50-59$ & $40-49$ & - & - & $21 \%$ & 19 & $x$ & $\mathrm{D}$ \\
\hline Michael & $\begin{array}{c}\text { Black } \\
\text { (African) }\end{array}$ & Christian & $\begin{array}{l}\text { Secondary } \\
\text { school, no } \\
\text { certificate }\end{array}$ & $\begin{array}{l}\text { Single, never } \\
\text { married }\end{array}$ & - & $20-29$ & $20-29$ & 1 & $10-19$ & $22 \%$ & 18 & $\checkmark$ & $\mathrm{R}$ \\
\hline Richard & $\begin{array}{l}\text { White } \\
\text { (British) }\end{array}$ & - & $\begin{array}{c}\text { Trade/ } \\
\text { technical/ } \\
\text { vocational }\end{array}$ & $\begin{array}{l}\text { Single, never } \\
\text { married }\end{array}$ & - & $30-39$ & $30-39$ & $2-5$ & $20-29$ & $14 \%$ & 18 & $x$ & $\mathrm{R}$ \\
\hline Thomas & $\begin{array}{l}\text { White } \\
\text { (British) }\end{array}$ & - & A-levels & Separated & Daily care & $40-49$ & $30-39$ & - & - & $32 \%$ & 17 & $x$ & $\mathrm{R}$ \\
\hline Luke & $\begin{array}{l}\text { White } \\
\text { (British) }\end{array}$ & Christian & GCSES & $\begin{array}{c}\text { Married/ } \\
\text { domestic } \\
\text { partnership }\end{array}$ & Daily care & $20-29$ & $20-29$ & - & - & $32 \%$ & 15 & $x$ & $\mathrm{D}$ \\
\hline
\end{tabular}

${ }^{13}$ Does not account for time served on remand.

${ }^{14} \mathrm{R}=$ randomly, $\mathrm{D}=$ by direct approach 


\begin{tabular}{|c|c|c|c|c|c|c|c|c|c|c|c|c|c|}
\hline Pseudonym & $\begin{array}{l}\text { Self- } \\
\text { reported } \\
\text { ethnicity }\end{array}$ & Religion & $\begin{array}{c}\text { Highest } \\
\text { education } \\
\text { completed? }\end{array}$ & Marital status & $\begin{array}{c}\text { Children } \\
\text { before } \\
\text { prison? }\end{array}$ & Age & $\begin{array}{l}\text { Age when } \\
\text { sentenced }\end{array}$ & $\begin{array}{l}\text { Previous } \\
\text { sentences }\end{array}$ & $\begin{array}{c}\text { Age at } \\
\text { earliest } \\
\text { prior } \\
\text { conviction }\end{array}$ & $\begin{array}{c}\text { Tariff } \\
\text { served }^{13}\end{array}$ & $P Q$ & $\begin{array}{l}\text { Considers } \\
\text { himself } \\
\text { guilty as } \\
\text { charged? }\end{array}$ & $\begin{array}{c}\text { How } \\
\text { selected? }^{14}\end{array}$ \\
\hline Martin & $\begin{array}{c}\text { White } \\
\text { (Gypsy or } \\
\text { Irish } \\
\text { Traveller) }\end{array}$ & Christian & GCSES & Separated & Daily care & $40-49$ & $30-39$ & $\geq 10$ & $10-19$ & $28 \%$ & 12 & $\checkmark$ & $\mathrm{R}$ \\
\hline Max & $\begin{array}{l}\text { White } \\
\text { (Other) }\end{array}$ & Christian & $\begin{array}{l}\text { Bachelors } \\
\text { degree }\end{array}$ & $\begin{array}{l}\text { Missing/ } \\
\text { unclear }\end{array}$ & $\begin{array}{l}\text { Shared } \\
\text { custody }\end{array}$ & $40-49$ & $30-39$ & 1 & $20-29$ & $32 \%$ & 11 & $\checkmark$ & $\mathrm{R}$ \\
\hline Regis & $\begin{array}{c}\text { Black } \\
\text { (Caribbean) }\end{array}$ & Muslim & GCSES & $\begin{array}{l}\text { Single, never } \\
\text { married }\end{array}$ & - & $20-29$ & $20-29$ & - & - & $33 \%$ & 11 & $\checkmark$ & $\mathrm{R}$ \\
\hline James & $\begin{array}{l}\text { White } \\
\text { (other) }\end{array}$ & Jewish & $\begin{array}{l}\text { Secondary } \\
\text { school, no } \\
\text { certificate }\end{array}$ & Divorced & $\begin{array}{c}\text { No } \\
\text { custody }\end{array}$ & $40-49$ & $30-39$ & $\geq 10$ & $10-19$ & $38 \%$ & 9 & $x$ & $\mathrm{R}$ \\
\hline John & $\begin{array}{c}\text { Mixed } \\
\text { (White and } \\
\text { Black } \\
\text { African) }\end{array}$ & Christian & GCSES & Separated & $\begin{array}{c}\text { Adult } \\
\text { children }\end{array}$ & $50-59$ & $40-49$ & $2-5$ & $20-29$ & $52 \%$ & 9 & $\checkmark$ & $\mathrm{R}$ \\
\hline Danny & $\begin{array}{l}\text { White } \\
\text { (British) }\end{array}$ & Buddhist & None & $\begin{array}{l}\text { Single, never } \\
\text { married }\end{array}$ & $\begin{array}{l}\text { Missing/ } \\
\text { unclear }\end{array}$ & $30-39$ & $20-29$ & - & - & $33 \%$ & 7 & $\checkmark$ & $\mathrm{R}$ \\
\hline Owen & $\begin{array}{l}\text { White } \\
\text { (British) }\end{array}$ & Other & Diploma & $\begin{array}{l}\text { Missing/ } \\
\text { unclear }\end{array}$ & - & $30-39$ & $20-29$ & $2-5$ & $20-29$ & $36 \%$ & 6 & $\checkmark$ & $\mathrm{R}$ \\
\hline Andy & $\begin{array}{l}\text { White } \\
\text { (British) }\end{array}$ & Christian & GCSES & $\begin{array}{c}\text { Married/ } \\
\text { domestic } \\
\text { partnership }\end{array}$ & - & $30-39$ & $10-19$ & 1 & $10-19$ & $67 \%$ & 5 & $\checkmark$ & $\mathrm{D}$ \\
\hline
\end{tabular}




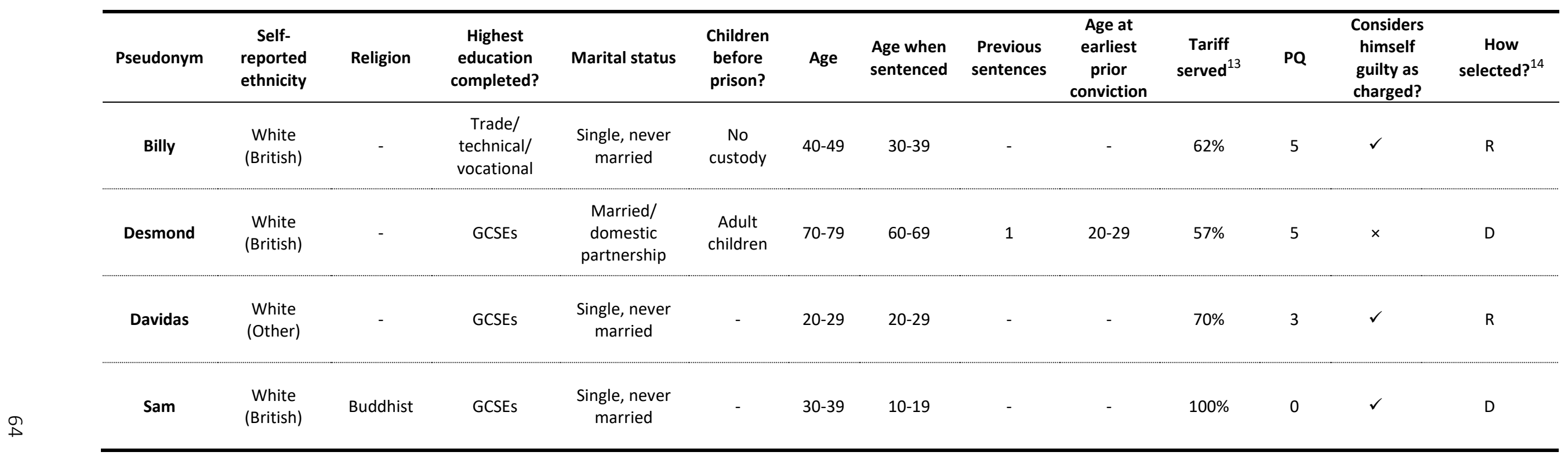

Table 4: Mean demographic data for the analytical groups, sorted in descending PQ order

\begin{tabular}{|c|c|c|c|c|c|c|c|c|c|}
\hline Group & Age & $\begin{array}{l}\text { Age when } \\
\text { sentenced }\end{array}$ & $\begin{array}{l}\text { Years } \\
\text { served }\end{array}$ & $\begin{array}{c}\text { Complete } \\
\text { years at } \\
\text { Gartree }^{15}\end{array}$ & $\begin{array}{l}\text { Tariff in } \\
\text { years }\end{array}$ & $\begin{array}{c}\text { Years to } \\
\text { tariff } \\
\text { expiry }\end{array}$ & $\begin{array}{c}\text { Age at } \\
\text { tariff } \\
\text { expiry }\end{array}$ & $P Q$ & $\begin{array}{c}\text { Age at } \\
\text { first } \\
\text { conviction }\end{array}$ \\
\hline Defensive agents $(n=7)$ & 43.4 & 37.4 & 5.4 & 3.9 & 21.1 & 15.3 & 59.0 & 15.3 & 26.4 \\
\hline Redemptive agents $(n=3)$ & 48.3 & 40.0 & 7.3 & 6.0 & 19.3 & 11.0 & 59.7 & 11.0 & 19.3 \\
\hline Corrective agents $(n=6)$ & 29.3 & 21.0 & 8.0 & 4.8 & 15.7 & 7.2 & 37.2 & 7.2 & 19.2 \\
\hline Fractured agents $(n=2)$ & 37.0 & 31.0 & 6.0 & 2.0 & 12.5 & 6.0 & 43.5 & 6.0 & 31.0 \\
\hline All $(n=18)$ & 38.8 & 31.7 & 6.7 & 4.3 & 18.1 & 10.8 & 50.1 & 10.8 & 23.3 \\
\hline
\end{tabular}

${ }^{15}$ During current stay - i.e. if the prisoner was transferred and returned later, this is not accounted for. 
Table 5: Original eligibility criteria, and whether they were applied

\begin{tabular}{|c|c|c|}
\hline Original criterion & Rationale & $\begin{array}{l}\text { Actually used to } \\
\text { generate the } \\
\text { sample? }\end{array}$ \\
\hline $\begin{array}{l}\text { Sentence } \geq 10 \text { years } \\
\text { (or tariff } \geq 10 \text { years if } \\
\text { life-sentence) }\end{array}$ & $\begin{array}{l}\text { Targets persistent/serious offenders serving long } \\
\text { sentences - those who might be supposed to } \\
\text { have had a 'criminal identity' before prison }\end{array}$ & $\checkmark$ \\
\hline$\geq 2$ prior convictions & Ditto & $x$ \\
\hline $\begin{array}{c}\text { Already served } \geq 2 \\
\text { years since sentencing }\end{array}$ & $\begin{array}{l}\text { Limit initial 'disorientation' - time for the } \\
\text { sentence to 'sink in' }\end{array}$ & $\checkmark$ \\
\hline Not on recall & $\begin{array}{l}\text { Focus the study only on the effects of the prison } \\
\text { environment }\end{array}$ & $\checkmark$ \\
\hline
\end{tabular}




\section{Appendix 3: O’Donnell's pain quotient}

O'Donnell, theorising how prisoners experience the passing of time, describes the 'pain quotient' or $P Q$ of a sentence as follows: $P Q=\frac{\text { time to be served }}{\text { life to be lived }}$. This, he says, is an objective way to describe the subjective burden of prison time, which may be experienced as more or less bearable depending on the characteristics of the sentence and the prisoner's position in the life course (O'Donnell 2014:201-5).

Life expectancy at birth for UK males was taken from a published dataset (World Bank 2016); values were regressed from available data for births before the start of the dataset in 1960. Calculating PQ exactly as O'Donnell describes results in negative denominators for individuals who have lived past the average life expectancy for their year of birth, rendering them incommensurable. PQ was therefore calculated as follows: $P Q=\frac{y_{t e}}{\text { rank }_{l e}}$, where $y_{t e}$ is years to tariff expiry, and $r_{a n k_{l e}}$ is the individual's percentage rank in the population, in ascending order of remaining life expectancy. This eliminated negative values, but as Desmond's case illustrates, it did not eliminate incommensurability; using data to estimate what O'Donnell intended as a subjective concept misses the fact that for people who expect to die in prison, the pains of imprisonment may be qualitatively different and especially acute (see Liebling 2017).

PQ has not, so far as I know, been empirically tested. This study did not set out to do so, and PQ is not a key concept in the analysis. It was selected pragmatically for sampling purposes, as a crude but theoretically coherent way to blindly select cases according to consistent and replicable criteria. 


\section{Appendix 4: Interview schedules}

Primary schedule 16

\section{'Warm-up' questions/outline of the sentence}

1. If I was to make a film about your life before this prison sentence, what kind of character would you be?

2. When you first came to prison on this sentence, would you say that you were interested in the possibility of changing as a person while you were in prison?

3. Could you start by spending a few minutes telling me about the key moments in your current sentence?

\section{Appreciative questions / introducing the idea of identity change}

4. What are you most proud of during your time in prison?

5. Think of someone important to you, someone you haven't seen since you came to prison. [pause - have you got someone in mind?] If you were released today, and you spent time with them, do you think they'd notice any changes in you?

What kinds of events, relationships and opportunities precipitate changes in identity?

6. You've described some changes, like [xxx]. How did those changes start?

7. Are there any particular people who have been important in the change process?

8. Are there any particular places in prison that have been important in the change process?

9. How would you describe the process of change?

10. What have you gained as a result of the changes you've described?

11. At the moment, who in your life believes in the changes you've described?

To what extent does penal power reinforce and support (and to what extent does it hinder) identity change?

12. What do you see as the purpose of imprisonment?

13. How easy is it to change as a person, in a place like Gartree?

14. What does the prison expect from you, in terms of change?

15. What about other prisoners, what are their expectations of you?

16. What kinds of opportunities are there to show who you really are?

17. How do you know when changes in yourself are real?

18. Compared to before, are there activities, people or places in the prison that you worry about or even avoid now?

\section{Under what circumstances do prisoners encounter 'turning points' or 'dead ends'?}

19. If you look back over the sentence so far, and the changes you've described, do you perceive any turning points?

20. Have there been any false starts?

21. Have there been painful or difficult moments along the way?

22. Is your sense of your future different now?

Participation in prison social life

\footnotetext{
${ }^{16}$ This was used as the basis for all but two interviews.
} 
23. How is your life in prison different now as a result of the changes you've described?

24. What's your main daytime activity at the moment?

25. How do you come across differently on the wing now, compared to before?

26. When you're not at work/education/[whatever], how do you pass your time?

27. Are you involved in any religious or spiritual activities in the prison?

28. Have you got into trouble with the prison authorities since you were sentenced?

\section{'Warm-down' questions}

29. What made you decide to come along here for this interview today?

30. Thinking about the things we've talked about, are there any questions I should have asked but didn't?

31. Is there anything you want to say anything else about?

32. Is there anything in the interview you've found difficult to talk about?

\section{'Shadow' schedule 17}

\section{'Warm-up' questions/outline of the sentence}

1. If I was to make a film about your life before this prison sentence, what kind of character would you be?

2. Could you start by spending a few minutes telling me about the key moments in your current sentence?

\section{Appreciative questions / introducing the idea of identity change}

3. What are you most proud of during your time in prison?

4. Think of someone important to you, someone you haven't seen since you came to prison. [pause - have you got someone in mind?] If you were released today, and you spent time with them, do you think they'd notice any changes in you?

5. [if the interviewee feels no changes would be noticed in them] When you first came to prison on this sentence, would you say you were interested in the possibility of changing as a person during your sentence?

To what extent does penal power reinforce and support (and to what extent does it hinder) identity change?

6. You said before it was a concern for you not to change. Is it difficult to remain unchanged in a place like Gartree?

7. What do you think the prison expects from you as a prisoner here?

8. What about other prisoners, what are their expectations of you?

9. Would you lose anything by changing?

10. Do you see other people in here who present themselves as changed men?

\section{Under what circumstances do prisoners encounter 'turning points' or 'dead ends'?}

11. You've said that you're [not interested in changing/find it difficult to change/what was said]. Looking back over the sentence, would you say there were any moments that could have been turning points, but turned out not to be?

\footnotetext{
${ }^{17}$ This was used as the basis for two interviews where interviewees indicated, in response to the 'warmup' questions, that not changing during imprisonment was a significant concern for them. It is substantially similar to, but alters the sequencing and (sometimes) the wording of, the primary schedule.
} 
12. Have you found yourself wanting to change but not feeling able to for some reason?

13. What's your view of the future like now, compared to when you first came to prison on this sentence?

\section{Participation in prison social life}

14. What's your main daytime activity here at Gartree?

15. When you're not at work/education/[whatever], how do you pass your time?

16. Are you involved in any religious or spiritual activities in the prison?

17. Have you got into trouble with the prison authorities since you were sentenced?

What kinds of events, relationships and opportunities precipitate secondary desistance, and what might prevent it?

18. If you think back to the beginning of your sentence, did you expect prison to change you?

19. Does prison put pressure on you to change?

20. [if the interviewee has indicated that he thinks change is a realistic/legitimate thing to expect of prisoners] You've said that you didn't think you've changed while you've been in prison. But you've also said that you think prisons can and should expect people to change. [And you've also described xyz changes in yourself]. Is there anything that makes it hard for you to admit to changing?

\section{Warm-down questions}

21. What made you decide to come along here for this interview today?

22. Thinking about the things we've talked about, are there any questions I should have asked but didn't?

23. Is there anything you want to say anything else about?

24. Is there anything in the interview you've found difficult to talk about? 


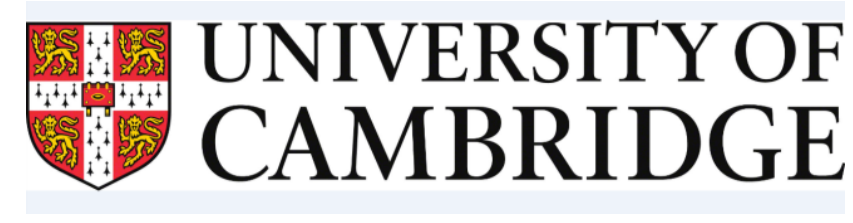

Project:

Identity, desistance, and the experience of imprisonment

Researcher:

Ben Jarman

\section{Who am I?}

I am a graduate student from the University of Cambridge. I am conducting research into how people experience imprisonment. Before this, I was employed for several years by charities working in prisons around England and Wales.

\section{Why am I doing this research?}

In my previous work, I became very interested in how people experience different prisons. I want to find out more about what kinds of things cause prisoners to perceive that they are changing. I'm interested in what makes people want to change, and what makes it possible for them to be accepted by others as a changed person. You'll be helping me to find out how the process gets started and what supports it, as well as what gets in the way.

\section{What will participation involve?}

If you agree to be involved, I will interview you, asking you to talk about your experiences in prison, and changes you have experienced while you have been inside. The interview may vary in length but will probably take no more than an hour and a half.

Do you have to take part?

No. Your participation is voluntary. If you don't want to be involved, you don't have to be involved. This will not cause you any disadvantage.

\section{Are there any risks involved in taking part?}

During the interview, I will ask you to talk about various aspects of your background and your sentence. Some questions might be about things you don't think about often, or which you prefer not to think about. Some questions might trigger unhappy or upsetting thoughts, although this is not very likely.

My priority is to avoid the interview causing you any harm. You can decide not to answer any particular question if you don't want to. You can also take a break or stop at any time if you want to. This won't count against you in any way. 
There will be time at the end of the interview to discuss anything you have found difficult, and that discussion won't form part of my research. If you like, you can also tell me the name of a Listener, a mentor, or a staff member whom you trust, before the interview begins. If you find the interview difficult, and want to talk more about it after the interview has finished, I can approach that named person on your behalf.

\section{Are there any benefits to taking part?}

I can't pay you for participating, but you will not lose pay if taking part means you miss work or education. Taking part will have no impact on your IEP level, or on any decision by the prison authorities about your parole or release arrangements. You might find that talking in confidence about your experience of prison is useful or helpful. People my colleagues have interviewed in prison in the past have often welcomed the chance to speak to someone neutral and independent, who was willing to listen to them. You will also be adding to our understanding of prison life.

\section{Will what you say be confidential?}

What you say will not be reported to anyone, unless it concerns the following:

- A risk to prison security;

- Offences you or someone else may have committed which have not been investigated or prosecuted;

- Any breach of prison rules that occurs during the interview;

- Anything you say that implies a threat to yourself or to anyone else.

The information you provide will be stored securely until the $31^{\text {st }}$ August 2017 , the end of my course. Anonymous transcripts of the interviews will be kept until $31^{\text {st }}$ August 2020 (see 'What will happen to the results of the study' below). The only person able to access these will be me.

\section{Will your contribution remain anonymous?}

Even if you are interviewed, you don't have agree to be quoted. However, if you do agree to be quoted, you will not be identifiable. I will give you a different name, as well as changing or leaving out any details about your life which could give away who you are.

\section{How do you agree to take part in the study?}

If you would like to take part please return the reply slip via the wing office to the research co-ordinator at HMP Gartree. The Psychology Department has agreed to collate the responses and let me know when I arrive at the prison who is interested. Please return the form within two days of receiving it. If you are not interested please also reply within two days so that I can then approach somebody else. If you are interested and if you agree to take part, l'll start the interview by asking you to confirm the following in writing:

- that you understand what is involved and have had a chance to discuss any questions you might have; 
- that you agree to take part

- whether you agree to be recorded and quoted.

If you agree to be recorded, the recording will be stored securely and destroyed as soon as I've turned it into a written record. The written record will not include your real name.

\section{What if you want to withdraw from the study?}

You can stop or take a break at any time, without giving a reason. If you change your mind later about taking part, you can also ask to be removed from the study. You can make this decision at any point up to $31^{\text {st }}$ May 2017. If you do, I will destroy all records of your interview. This will not disadvantage you in any way. If you do want to remove yourself from the study, you should write to me at the following address: Ben Jarman, Institute of Criminology, Sidgwick Avenue, Cambridge CB3 9DA.

\section{What will happen to the results of the study?}

The results of the study will form my thesis - an extended essay that I have to write for my course. I would like to carry out a further research project on this topic in the future. If I do, the interviews might also be used to help me think about that project. It is possible that I will want to talk about the research with prison staff or other researchers. If I do this, you won't be identifiable.

What if you want more information, or you want to make a complaint?

Further information about the study can be obtained by writing to my academic supervisor, Dr Ben Crewe, at the address below. If you would like to see the research when it is finished, I would be happy to send you a copy, in which case please write to the same contact. The plans for the study have been reviewed by staff at the prison, and by the Ethics Committee of the University of Cambridge Institute of Criminology. If you want further information about its ethics, or if you want to complain about some aspect of the research, you should write to Dr Crewe at the address given below:

$$
\begin{aligned}
& \text { Prisons Research Centre } \\
& \text { Institute of Criminology } \\
& \text { Sidgwick Avenue } \\
& \text { Cambridge CB3 9DA }
\end{aligned}
$$

Thank you for reading this information. If you have any further questions at any stage, you just need to ask! 


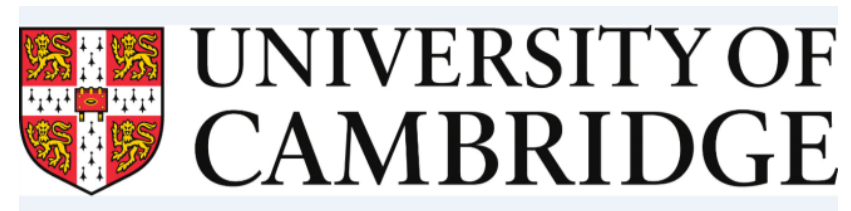

Project title: Identity, desistance, and the experience of imprisonment

Researcher: Ben Jarman

Please tick the boxes if you agree with the following three statements.

1. I have read and understood the information sheet, and have had a chance to ask questions about the study.

2. I understand that I can choose not to answer any question, and that I can withdraw from the study at any time until $31^{\text {st }}$ May 2017.

3. I agree to take part in the study, which means being interviewed by the researcher.

Please tick a box to answer YES or NO to the following statements.

4. I agree to the interview being recorded and understand that the recording will be destroyed after it has been transcribed.

5. I agree that the researcher can use quotes from our interviews and conversations, and understand my identity will be disguised. 
Name of Participant:

Date:

Signature:

Name of Researcher: Ben Jarman

Date:

Signature:

To be completed by the researcher:

Personal identifier:

Participant's research code: 


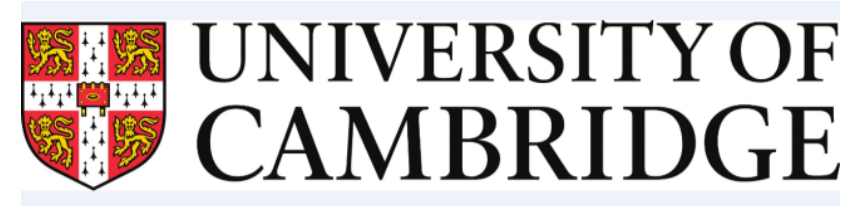

Project title: Identity, desistance, and the experience of imprisonment

Researcher: Ben Jarman

\begin{tabular}{|l|l|}
\hline $\begin{array}{l}\text { Your name } \\
\text { Participant ID (to be } \\
\text { completed by the } \\
\text { researcher) }\end{array}$ & \\
\hline $\begin{array}{l}\text { What is your gender? } \\
\text { Date of birth }\end{array}$ & \\
\hline $\begin{array}{l}\text { What date were you } \\
\text { sentenced? }\end{array}$ & \\
\hline $\begin{array}{l}\text { Date when your tariff } \\
\text { expires }\end{array}$ & \\
\hline $\begin{array}{l}\text { Is this your first prison } \\
\text { sentence? }\end{array}$ & $\square$ Yes \\
\hline $\begin{array}{l}\text { (if 'No', please tick } \\
\text { how many sentences } \\
\text { you have had before) }\end{array}$ & $\square$ Once before \\
\hline $\begin{array}{l}\text { How old were you } \\
\text { when you were first } \\
\text { convicted? }\end{array}$ & \\
\hline $\begin{array}{l}\text { How long have you } \\
\text { been in prison on this } \\
\text { sentence? }\end{array}$ & \\
\hline $\begin{array}{l}\text { How long have you } \\
\text { been in this particular } \\
\text { prison (i.e. Gartree)? }\end{array}$ & \\
\hline $\begin{array}{l}\text { I consider myself } \\
\text { guilty as charged for } \\
\text { the offence I was } \\
\text { convicted of }\end{array}$ & \\
\hline
\end{tabular}




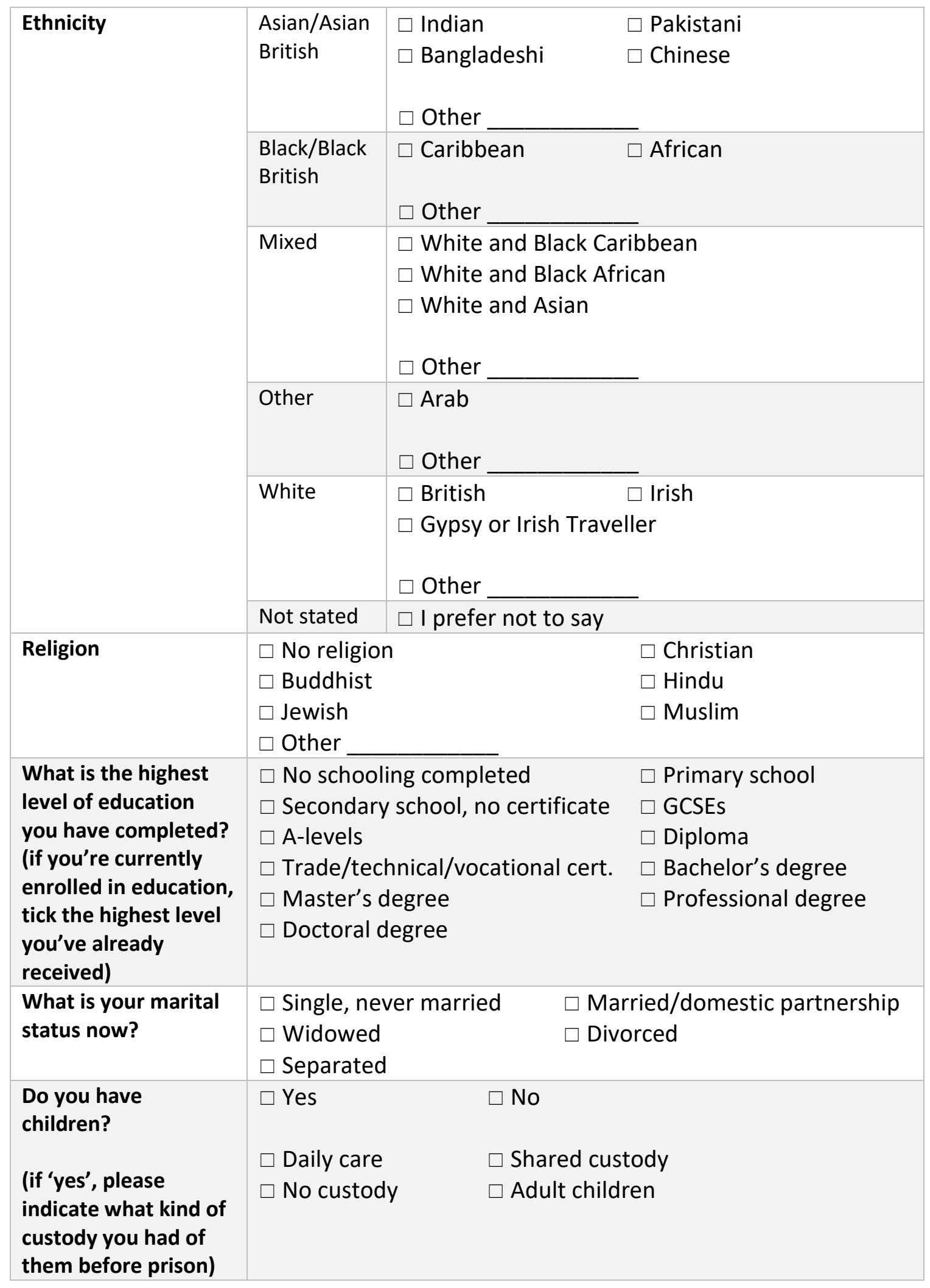

